Article

\title{
Assessing Crop Water Requirements and a Case for Renewable-Energy-Powered Pumping System for Wheat, Cotton, and Sorghum Crops in Sudan
}

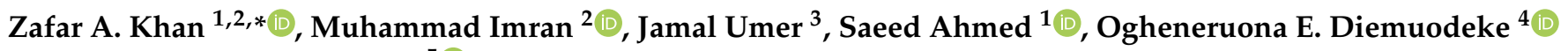 \\ and Amged Osman Abdelatif 5 (D) \\ 1 Department of Electrical Engineering, Mirpur University of Science and Technology, \\ Mirpur 10250, Pakistan; saeed.ahmed@must.edu.pk \\ 2 Mechanical, Biomedical and Design Engineering, College of Engineering and Physical Sciences Aston \\ University, Birmingham B4 7ET, UK; m.imran12@aston.ac.uk \\ 3 Department of Mechanical Engineering, University of Engineering and Technology Lahore, \\ Lahore 54890, Pakistan; jamalumer@uet.edu.pk \\ 4 Energy and Thermofluid Research Group, Department of Mechanical Engineering, Faculty of Engineering, \\ University of Port Harcourt, Port Harcourt 500102, Nigeria; ogheneruona.diemuodeke@uniport.edu.ng \\ 5 Department of Civil Engineering, Faculty of Engineering, University of Khartoum, Khartoum 51111, Sudan; \\ Amged.Abdelatif@uofk.edu \\ * Correspondence: zafarakhan@ieee.org
}

check for updates

Citation: Khan, Z.A.; Imran, M.; Umer, J.; Ahmed, S.; Diemuodeke, O.E.; Abdelatif, A.O. Assessing Crop Water Requirements and a Case for Renewable-Energy-Powered Pumping System for Wheat, Cotton, and Sorghum Crops in Sudan. Energies 2021, 14, 8133. https:// doi.org/10.3390/en14238133

Academic Editor: Donato Morea

Received: 4 November 2021

Accepted: 29 November 2021

Published: 4 December 2021

Publisher's Note: MDPI stays neutral with regard to jurisdictional claims in published maps and institutional affiliations.

Copyright: (c) 2021 by the authors. Licensee MDPI, Basel, Switzerland. This article is an open access article distributed under the terms and conditions of the Creative Commons Attribution (CC BY) license (https:/ / creativecommons.org/licenses/by/ $4.0 /)$.

\begin{abstract}
Climate change is changing global weather patterns, with an increase in droughts expected to impact crop yields due to water scarcity. Crops can be provided with water via underground pumping systems to mitigate water shortages. However, the energy required to pump water tends to be expensive and hazardous to the environment. This paper explores different sites in Sudan to assess the crop water requirements as the first stage of developing renewable energy sources based on water pumping systems. The crop water requirements are calculated for different crops using the CROPWAT and CLIMWAT simulation tools from the Food and Agriculture Organization (FAO) of the United Nations. Further, the crop water requirements are translated into electrical energy requirements. Accurate calculations of the energy needed will help in developing cost-effective energy systems that can help in improving yields and reducing carbon emissions. The results suggest that the northern regions tend to have higher energy demands and that the potential for renewable energy should be explored in these regions, which are more susceptible to drought and where crops tend to be under higher stress due to adverse climate conditions.
\end{abstract}

Keywords: agriculture; CROPWAT; irrigation management; crop water requirement

\section{Introduction}

Agriculture is considered to be the backbone of Sudan's economy, with an approximate contribution of up to one-third of the total GDP and with an estimated 39\% of workers employed in the sector [1]. Sudan was known as an Arab breadbasket in the 1970s, having high agricultural exports. However, a lack of resources and climate change exacerbated stresses for Sudanese people already struggling with poverty and environmental degradation, which impact those in rural areas more severely. The population of Sudan increased to 45 million in 2021, up from 31 million in 2008 [1]. This increasing population requires more food, while the effects of climate change are imminent, involving changing weather patterns and droughts that increase uncertainty, resulting in a high risk to food security. Moreover, the use of fossil fuels to meet the energy demands exacerbates the impacts of climate change.

According to the Köppen-Geiger climate classification map of Sudan [2], as can be seen in Figures 1 and 2, most of the northern part of the country comes under the arid or 
desert climate classification (BWh), with very low rainfall that mainly occurs in July and August. The southern part has a semi-arid or semi-desert (BSh) climate, with maximum rainfall from June to September [3-5]. A small southern portion of the country has a tropical savanna climate $(\mathrm{Aw})$ and experiences frequent rainfall from May to October. The rainfall data were collected from the CRU TS 3.21 dataset, which contains monthly average rainfall rates from 1901 to 2012 [4]. The lack of rain in large areas renders agriculture practices unproductive, since a large area of the country is totally dependent on rain.

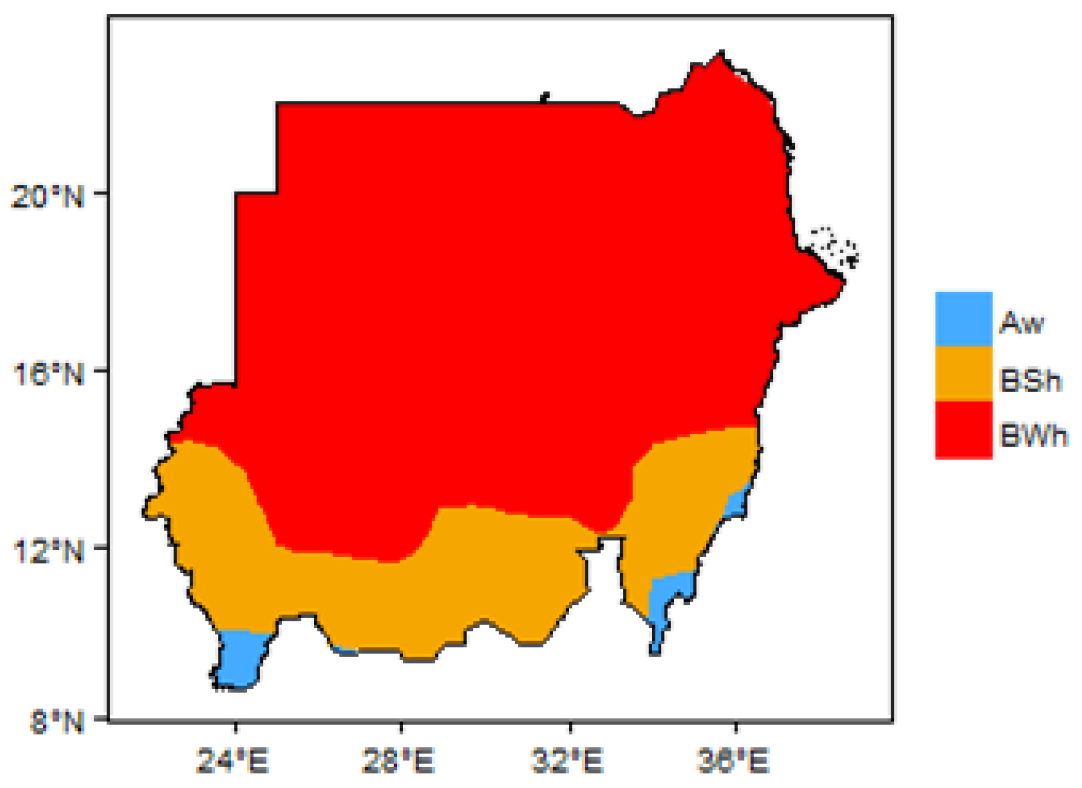

Figure 1. Köppen-Geiger climate classification map of Sudan [2].

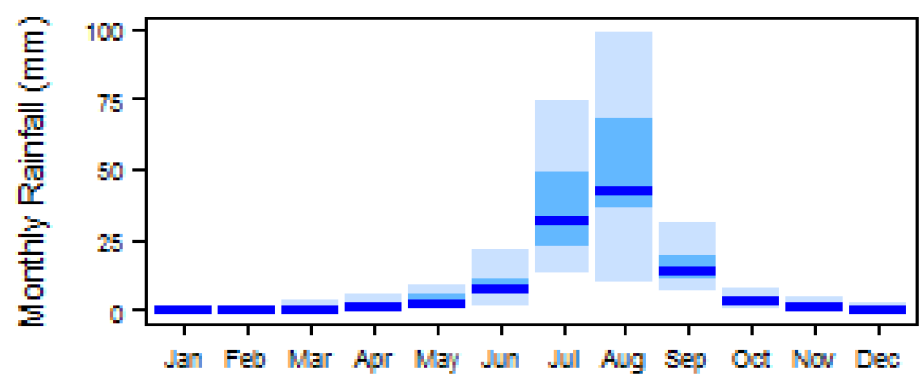

(a)

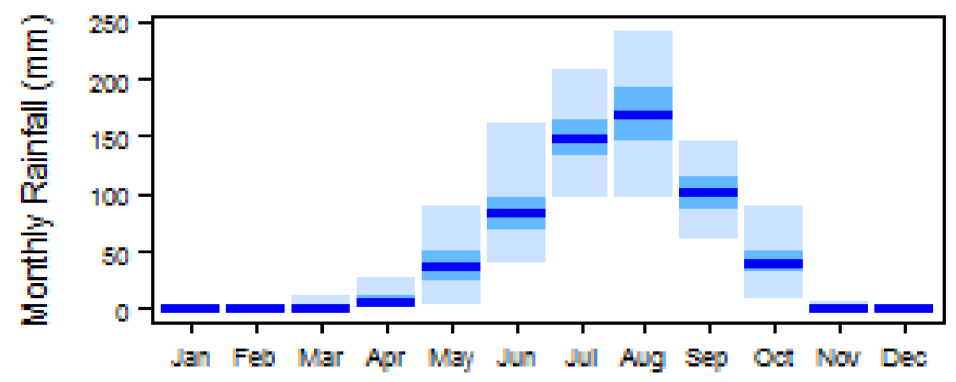

(b)

Figure 2. Cont. 


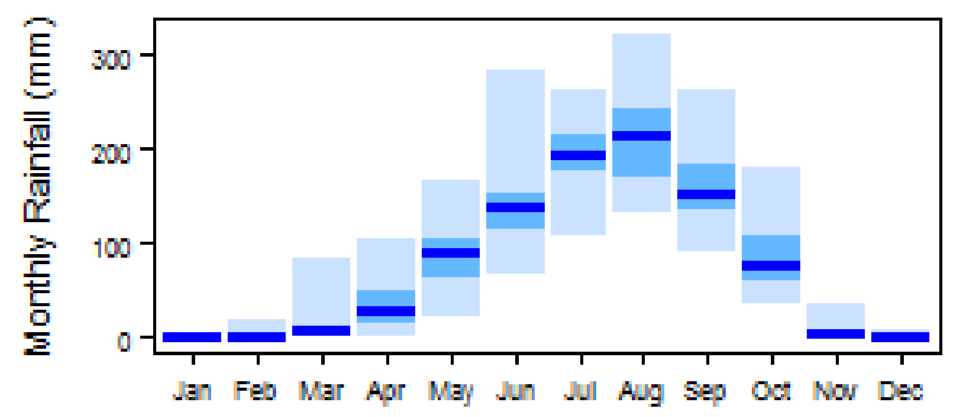

(c)

Figure 2. Average rainfall amounts in different climatic regions of Sudan [5] ( $x$-axis shows month of year and $y$-axis show monthly rainfall in $\mathrm{mm}$ ): (a) rainfall in arid/desert (BWh) regions; (b) rainfall in semi-desert (BSh) regions; (c) rainfall in tropical savanna (Aw) regions.

Agriculture in countries with mostly arid climates tends to struggle. Moreover, global warming and climate change are also suppressing crop yields. Droughts are expected to continue to impose immense pressure on food security in fragile ecosystems [6]. Global leaders have come together to reduce greenhouse gas emissions to control climate change, although the crops of today should be ready to endure new stresses, such as increasing droughts due to climate change, or these stresses should be managed via alternate options. To endure these stresses, the role of symbiotic microorganisms in plant phenotypic adjustments to environmental stresses has been explored in different studies [7-10]. According to the authors of [11], fungal endophytes, an important constituent of the plant microbiome, may be key to the ability of plants to adapt to climatic stressors. Although these are interesting solutions that must be explored and adopted, immediate solutions to reduce the stressors are required to mitigate the water needs of crops.

Sudan contains 175 million feddans (73.5 million hectares) of suitable agriculture land, although only 26 million hectares is currently being sown [1]. However, only 1 million hectares of the total arable land is irrigated, with 6.7 million hectares being managed using semi-mechanized rainfed agriculture methods and a whopping 9 million hectares being completely dependent on traditional rainfed agriculture methods. It is important to understand the climatic conditions in Sudan to fully understand the importance of irrigation for agriculture. However, in addition to Sudan, an overview of irrigation water requirements in Africa as whole shows that countries in Northern Africa tend to have higher crop water requirements, as shown by the in-out values for 53 countries (Figure 3), with 15 countries having irrigation water requirement rates greater than $1000 \mathrm{~mm}$. It is evident that these countries are in Northern Africa, with Sudan being one such country with high water demands. After the separation of South Sudan, Sudan's reliance on agriculture increased, meaning the irrigation water requirements consequently increased.

Despite the fact that the irrigation water requirements in Sudan are very high, the country has a higher percentage of cropland equipped with irrigation as compared to most other African countries. This is clear in Figure 4, showing that although the percentage of irrigation in Sudan is high, the country suffers from food insecurity.

The areas that are irrigated use the Nile River as the key source of water. Sudan has one of the largest irrigation schemes in the world, called the Jazirah scheme, which irrigates approximately 1 million hectares of the total 1.6 million hectares of irrigated land in Sudan [14]. Some studies have pointed out the irrigation management challenges in the Gezira scheme $[15,16]$; however, better planning could always be utilized to improve the irrigation management [17]. Apart from the river Nile, spate flows from seasonal rivers in the Gash and Tokar Deltas also contribute to irrigated agriculture [1]. Irrigated agriculture also benefits from rain in summer, e.g., the Suki irrigation scheme sources $40 \%$ of its water from rain. However, from the hydrogeology map of Sudan [18] presented in Figure 5, it 
can be observed that the country has abundant resources of underground water [18]. At the same time, from Figure 6 it is clear that the Nile is the main perennial river, while the rest of the rivers are non-perennial.

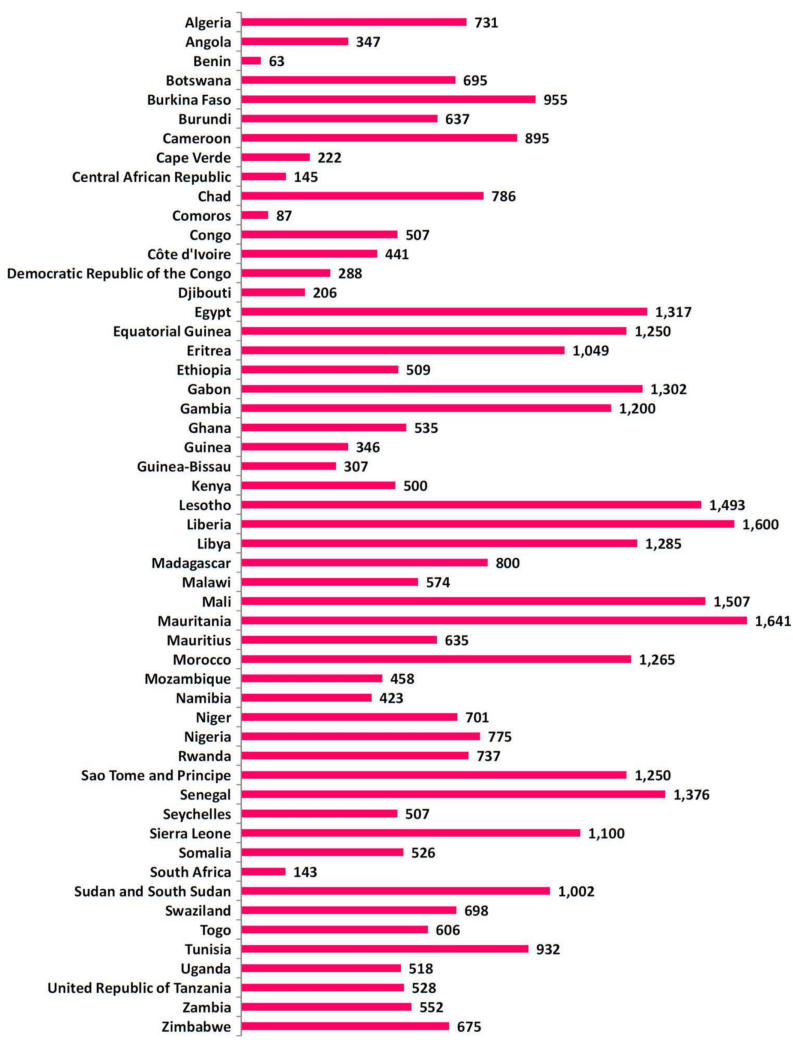

Figure 3. Irrigation water requirements (mm/year) in 2011 (in several cases the index values for the previous years are reported due to a lack of data) [12].

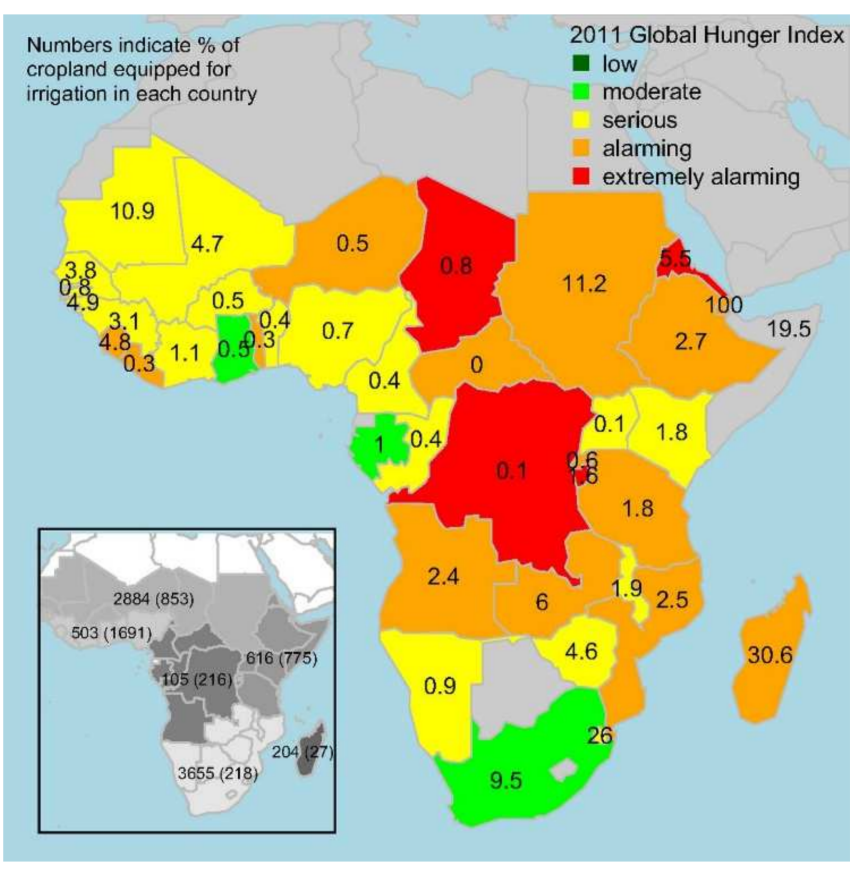

Figure 4. 2011 Global Hunger Index and irrigation coverage [13]. 


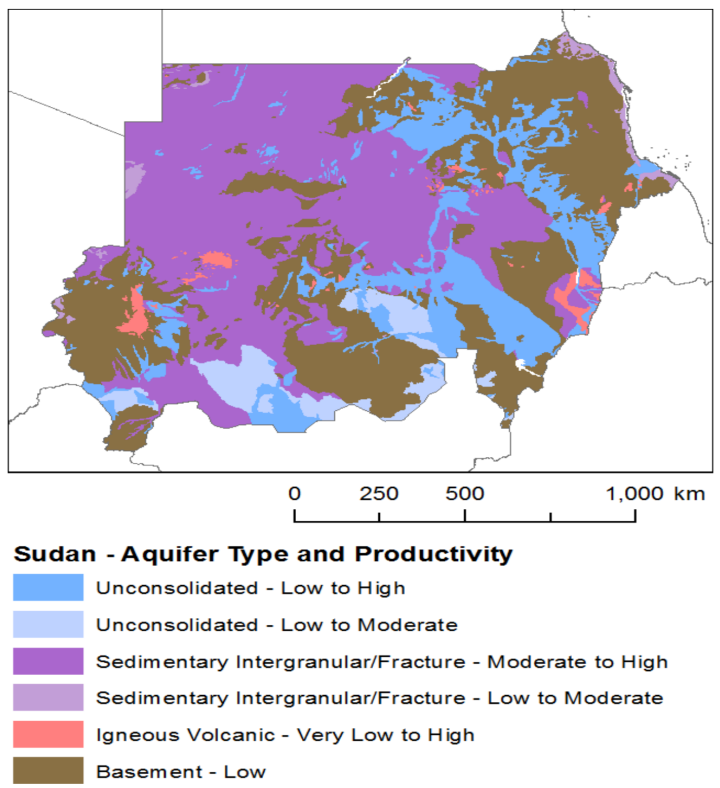

Figure 5. Hydrogeology of Sudan [18].

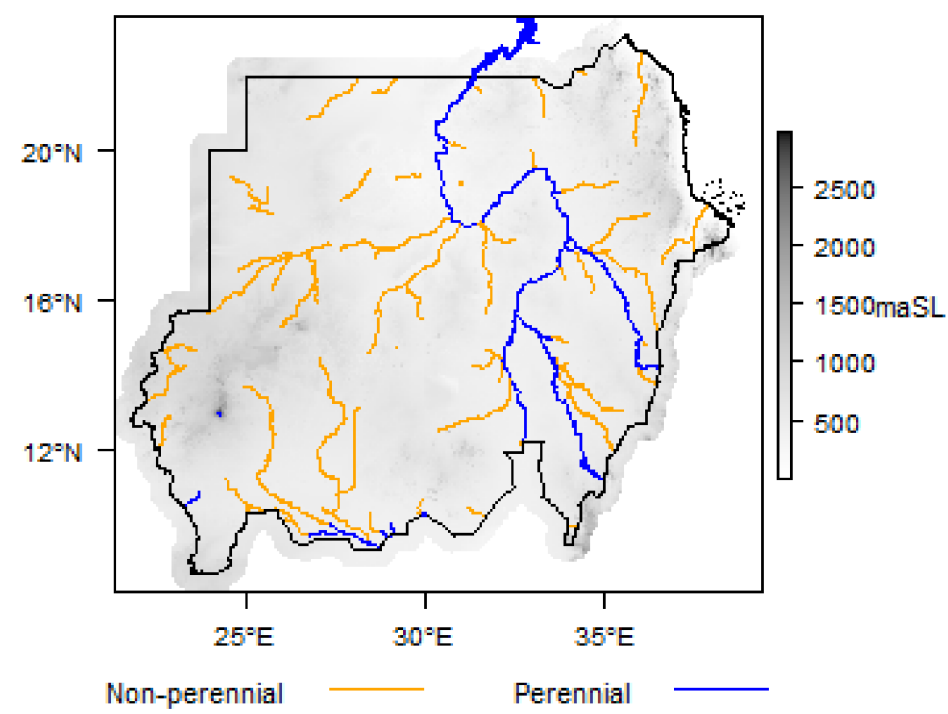

Figure 6. Major surface water features in Sudan [18].

Groundwater is the major source of water for locations away from the Nile basin and other non-Nelotic river wells. It is estimated that Sudan contains more than 900 billion cubic meters (BCM) of water reserves, with 1.563 BCM of annual recharge [19,20]. Despite having such an abundant amount of water to recharge aquifers, agriculture is still dependent on rain-fed conditions.

The utilization of the groundwater presents a multitude of challenges. The primary challenge in the utilization of groundwater is the lack of electricity in remote areas for water pumping $[15,16]$. Increasing fuel prices combined with increasing inflation make the utilization of diesel generators costly, hazardous for the environment, and financially unsustainable. Recent developments in renewable energy systems have increase their potential for utilization in irrigation. However, the costs of renewable energy sources such as solar photovoltaic (PV) systems are considered to be high due to the high initial capital costs [21,22]. Although there are many financing opportunities being provided by Sudan's government and international organizations such as the United Nations Development Program (UNDP) to promote renewable energy for sustainable agriculture, the accurate 
determination of water requirements dictates the cost and viability of renewable energy options. This cost is often overestimated due to a lack of knowledge regarding the crop water requirements. Oversizing incurs extra costs, while undersizing can lead to insufficient performance. This is why there is a need for scientific studies that consider irrigation holistically starting from the crop water requirements to determine the amount of energy required and to size the water pumping system.

Some studies have made efforts to determine the crop water requirements, e.g., Schumacher et al. [23] studied the water requirements for urban agriculture in Khartoum. Similarly, Elhag and Ahmed [14] analyzed the irrigation water requirements for the Gezira scheme, while Jabow et al. [24] explored the crop water requirements for tomato, common bean, and chickpea crops in Hudeiba, Sudan. However, a study that considers crop water requirements for different areas in Sudan is urgently required to enable meaningful water planning and the development of cost-effective sustainable irrigation systems across Sudan to alleviate food insecurity. This study seeks to fill this gap by establishing crop water requirements for important crops in Sudan, namely wheat, cotton, and sorghum crops. This will not only improve the knowledge regarding crop water requirements and help in determining the resources required but will also improve the planning process and water management for irrigation. Moreover, the limitation of the data required to calculate the average size of the water pumps is addressed by exploring crop water requirements for different areas and by calculating the amounts of energy required at all sites for each crop. The rest of the paper is organized as below.

Section 2 present the methodology adopted to calculate the crop water requirements and pump size. Section 3 delineates the case studies considered in this paper. The results of the case studies are presented in Section 4. Section 5 concludes the paper.

\section{Methodology}

Sudan is divided into 18 states for administrative purposes, as can be seen in Figure 7 [25]. However, as the aim of this study is to compare crop water requirements for different crops in different regions, two factors are considered herein for site selection. Firstly, the classification of Sudan according to climatic conditions (Figure 1) is considered as the crop water requirements are highly dependent on climate. Lastly, crop water requirements depend on the type of soil; thus, the soil map of Sudan given in Figure 8 is used to determine the soil types at selected sites for which soil data were not available. Thus, the selected areas are based on the different climatic conditions and dominant soil types.

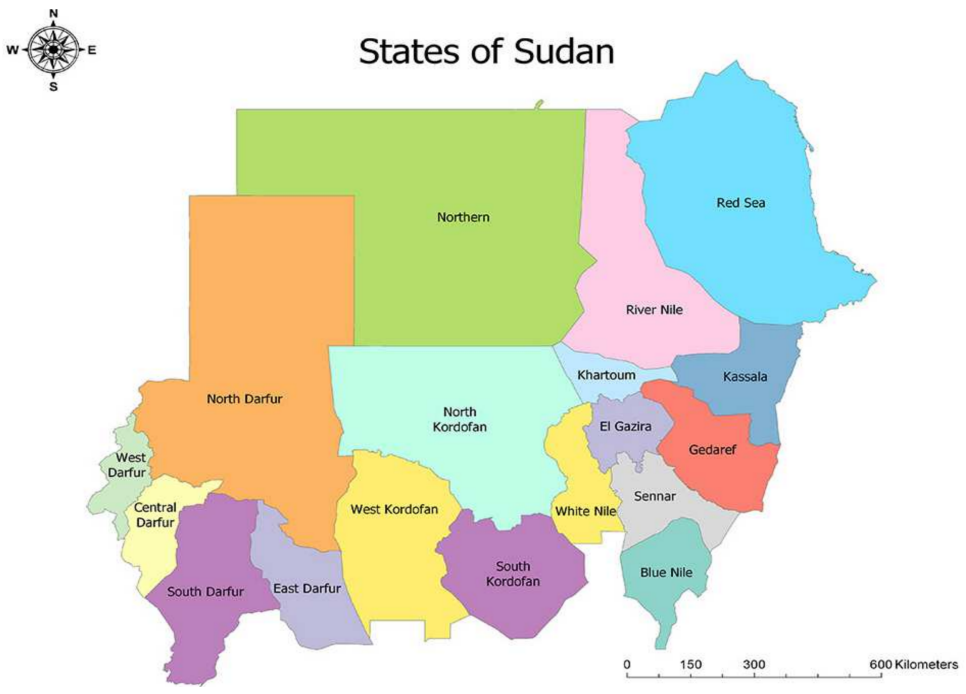

Figure 7. Different states of Sudan [25]. 


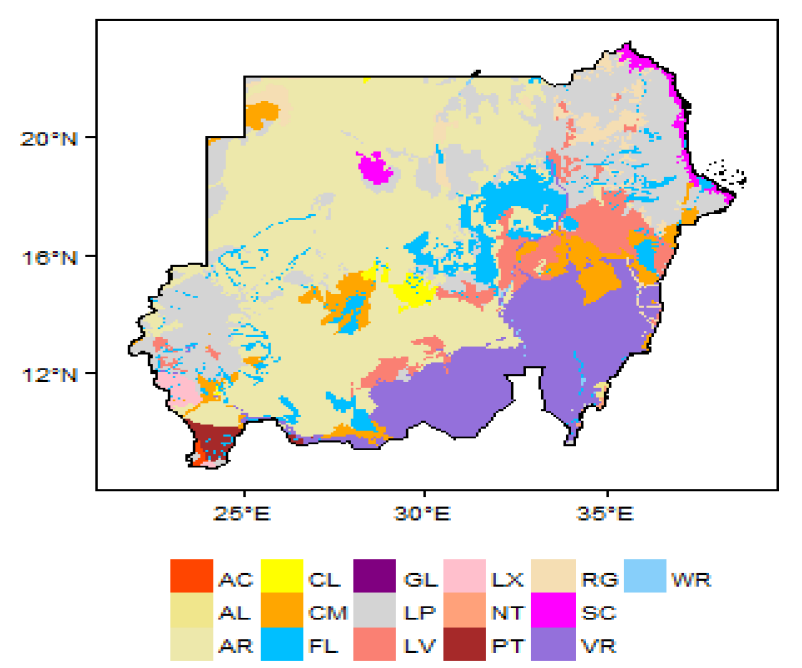

Figure 8. Soil map of Sudan [18]. Acrisols (AC), Alisols (AL), Calcisols (CL), Cambisols (CM), Fluvisols (FL), Gleysols (GL), Arenosols (AR), Leptosols (LP), Lixisols (LX), Luvisols (LV), Plinthosols (PT), Regosols (RG), Solonchaks (SC), Nitisols (NT), Vertisols (VR), Water Body (WR).

Once the study sites are selected, the process for the calculation of the crop water requirements is initiated. Here, the crop water requirements are assessed using CROPWAT software, which is a decision support system developed by the FAO of UN [15]. It considers a number of inputs, such as the crop type, soil type, and climatic data to calculate reference evapotranspiration $\left(\mathrm{ET}_{0}\right)$, crop evapotranspiration $\left(\mathrm{ET}_{\mathrm{c}}\right)$, net irrigation water requirement (NIWR), and gross irrigation water requirement (GIWR) values. To calculate the crop water requirements, the methodology presented in Figure 9 is adopted herein.

The calculation of the crop water requirements can be divided into three distinctive stages, i.e., data acquisition, computation of the $\mathrm{ET}_{\mathrm{c}}$, and computation of the effective rainfall. Soil data were obtained from the FAO database, which classifies soil types into different categories. The literature was used to correctly classify the soils at the selected sites [26]. The climatic data from the FAO [15] for long-term monthly averages for 15 years covering different periods from 1971 to 2000 are available in the CLIMWAT 2 module, which can be directly used in CROPWAT [15]. Although the dataset from CLIMWAT contains averaged data for a long period collected from over 5000 weather stations globally, considering the ongoing climate changes and carbon emissions, this dataset needs to be updated. However, due to a lack of data, the existing CLIMWAT dataset will be used. Apart from the rainfall and temperature data, the most important value is evapotranspiration. Transpiration and evaporation occur at the same time, and when combined with each other are often referred to as evapotranspiration (ET). The rate of ET from a hypothetical crop is called the reference evapotranspiration $\left(\mathrm{ET}_{0}\right)$. The rate of ET from a hypothetical crop with a height of $0.12 \mathrm{~m}$, albedo of 0.23 , and fixed canopy resistance of $70 \mathrm{sm}^{-1}$ is called the reference evapotranspiration [27].

The FAO CROPWAT model uses the FAO Penman-Monteith equation for the calculation of $\mathrm{ET}_{0}$ based on weather data [28]. The net irrigation water requirement is calculated using the crop evapotranspiration $\left(\mathrm{ET}_{\mathrm{c}}\right)$ and effective rainfall $\left(\mathrm{R}_{\mathrm{eff}}\right)$ values. The $\mathrm{ET}_{\mathrm{c}}$ is calculated using (1) [27]:

$$
\mathrm{ET}_{\mathrm{c}}=\mathrm{K}_{\mathrm{c}}+\mathrm{ET}_{\mathrm{o}}
$$

where $\mathrm{K}_{\mathrm{c}}$ is the crop coefficient. $\mathrm{K}_{\mathrm{c}}$ represents an integration of the effects of four essential qualities that differentiate the crops from the reference grass, which covers the albedo (reflectance) of the crop-soil surface, crop height, canopy resistance, and evaporation from the soil [29]. $\mathrm{K}_{\mathrm{c}}$ varies with the crop development and is divided into four different stages, i.e., initial, development, mid-season, and late-season stages. 


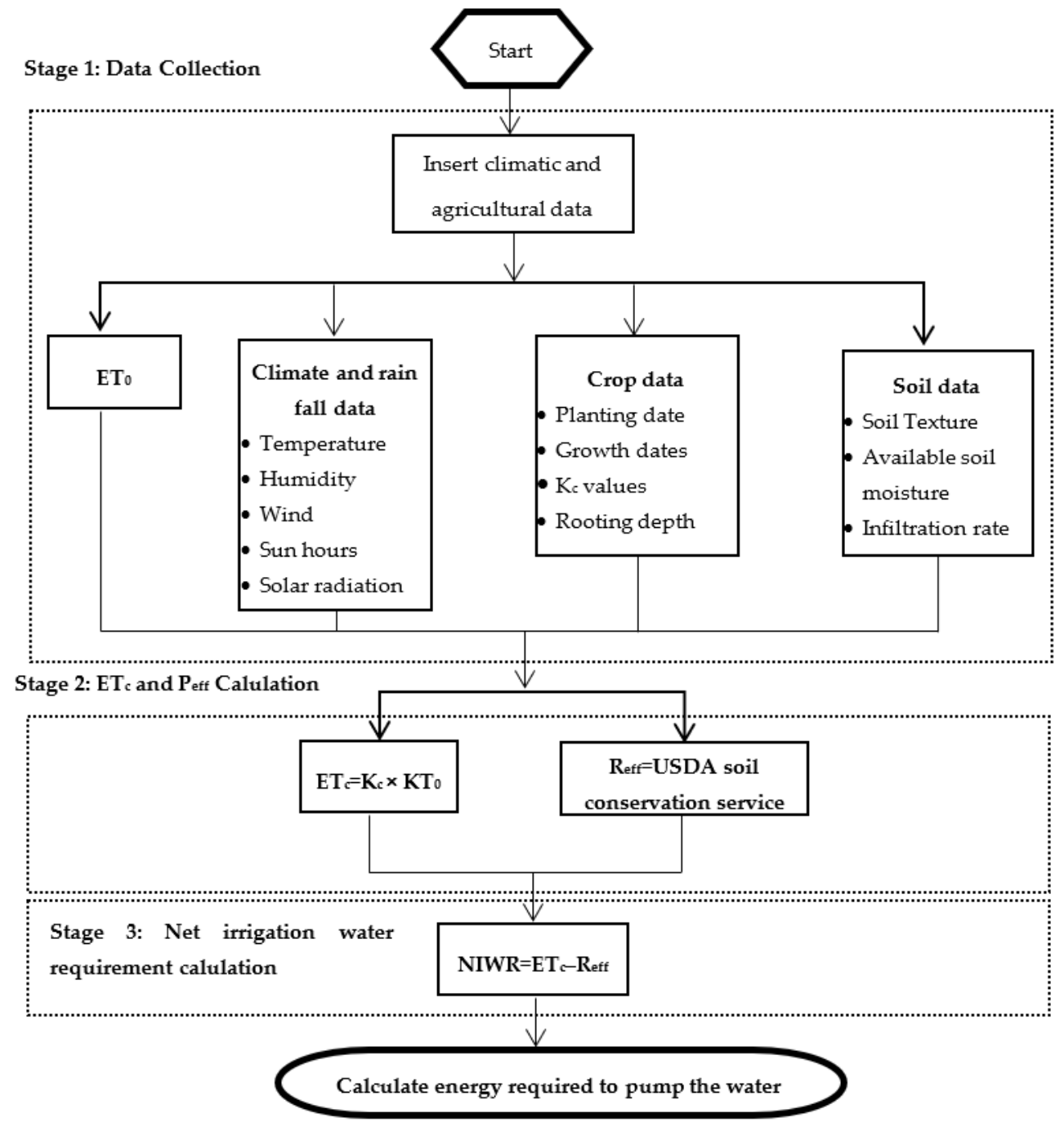

Figure 9. Flow chart of the crop water requirements and energy calculation.

The crop water requirement is defined as the amount of water needed to maintain the moisture level by identifying the water lost through evapotranspiration $\left(\mathrm{ET}_{\mathrm{c}}\right)$ for a diseasefree crop. Therefore, the crop water requirement essentially represents the $\mathrm{ET}_{\mathrm{C}}$ values obtained over different seasons. However, when calculating the irrigation requirements, other sources of water also need to be considered. If there is no rainfall, the $\mathrm{ET}_{\mathrm{c}}$ is considered to be the water required for the crop, whereas for rain or deep seepage, the net irrigation water requirement (NIWR) will be lower, as given in (2) [27]:

$$
\mathrm{NIWR}=\mathrm{ET}_{\mathrm{o}}-\mathrm{R}_{\mathrm{eff}}
$$

Once the crop water requirement is calculated, the total energy requirement to meet the crop water requirement is calculated. To calculate the power requirement, the total water discharge calculated using CROPWAT is used as in (3) [30]:

$$
P=Q g H \rho / 3.6 \times 10^{6}
$$

where $Q$ is the flow of water $\left(\mathrm{m}^{3} / \mathrm{s}\right), \rho$ is the density of water $\left(\mathrm{kg} / \mathrm{m}^{3}\right), g$ is the acceleration due to gravity $\left(\mathrm{m} / \mathrm{s}^{2}\right)$, and $H$ is the differential head $(\mathrm{m})$. Using (3), the power required to lift water is calculated in $\mathrm{kW}$, which can be converted into daily energy. 


\section{Case Study}

\subsection{Site Selection}

The site selection process requires two major inputs, rainfall and climatic data, as well as soil data. FAO CLIMWAT 2 provides the weather data from 66 weather stations across Sudan; however, soil data are not commonly available. For the purposes of site selection, a study was carried out by Shallah and Ahmed [31], which considered 10 different sites in different climatic areas, as shown in Figure 10. Apart from these sites, two more sites were selected, which are highlighted in red (sites 11 and 12) in Figure 10 [31].

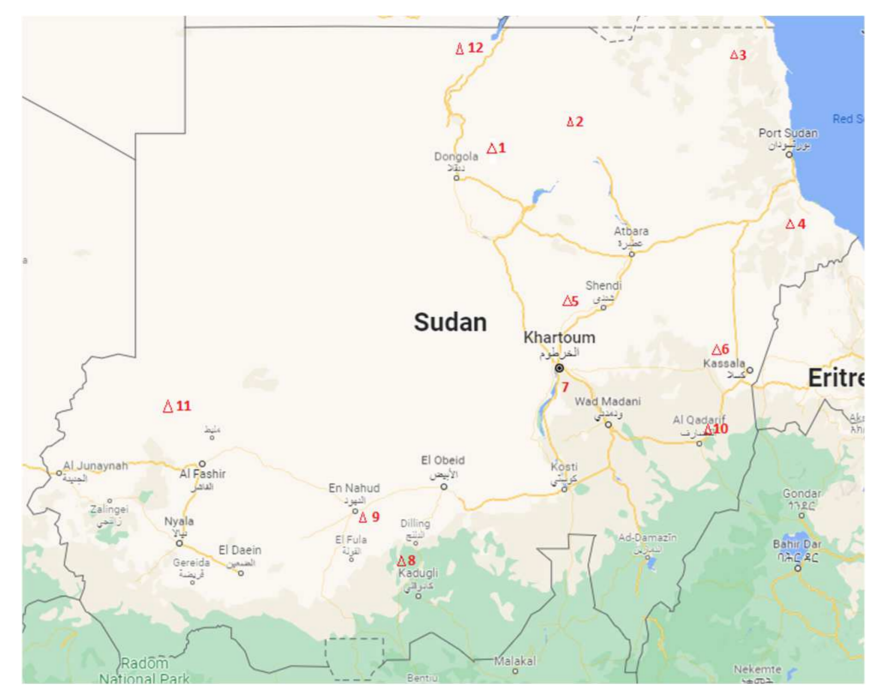

Figure 10. Selected sites used for case study.

The details of the locations and types of soil for the selected sites are given in Table 1. Although the purpose of the soil testing was not agricultural, shallow samples of up to $1.5 \mathrm{~m}$ can provide the information that can be used for soil classification. For CROPWAT, soil classification was adopted according to the FAO guidelines for soil description documents [26]. The location name for site 7 could not be found on the map, so an approximate location from the map presented in Figure 10 was used to allocate the nearest weather station.

Table 1. Site locations and soil types (adopted from [31]).

\begin{tabular}{|c|c|c|c|c|c|}
\hline No. & $\begin{array}{l}\text { Sample } \\
\text { Location }\end{array}$ & Climate Zone & $\begin{array}{l}\text { No. and Name of Nearest } \\
\text { Weather Station on CLIMEWAT }\end{array}$ & $\begin{array}{c}\text { Coordinates of } \\
\text { Weather Station } \\
\text { Long-Lat. }\end{array}$ & Soil Type \\
\hline 1 & $\begin{array}{l}\text { North East of } \\
\text { Karima }\end{array}$ & Arid & 54-Karima & $31.85-18.55$ & Poorly graded sand \\
\hline 2 & $\begin{array}{l}\text { South East of } \\
\text { Abuhamad }\end{array}$ & Arid & 63-Abu-Hamed & $33.31-19.53$ & $\begin{array}{l}\text { Poorly graded silty } \\
\text { sand }\end{array}$ \\
\hline 3 & Osaif & Arid & 8-Dongonab & $37.13-21.1$ & Silty sandy Gravel \\
\hline 4 & $\begin{array}{l}\text { South west of } \\
\text { Toker }\end{array}$ & Arid & 59-Tokar & $37.73-18.43$ & Silty Gravelly sand \\
\hline 5 & West of Almatama & Arid & 38-Khartoum & $32.55-15.6$ & Gravelly Silty sand \\
\hline 6 & Kassala & Semi Arid & 41-Kassala & $36.4-15.46$ & Silty Clay \\
\hline 7 & Elgurashi & Semi Arid & 27-Ed-Dueim & $32.33-14$ & Silty Clay \\
\hline 8 & Kadugli & Semi Arid & 9-Kadugli & $29.71-11$ & Sandy Silty Clay \\
\hline 9 & Almujlad & Semi Arid & 7-Babanusa & $27.81-11.33$ & Silty Clay \\
\hline 10 & Algadarif & Semi Arid & 34-Gadaref & $35.4-14.03$ & $\begin{array}{l}\text { Silty Clay (Expansive } \\
\text { soil) }\end{array}$ \\
\hline 11 & $\begin{array}{l}\text { Kutum North of } \\
\text { Darfur }\end{array}$ & Semi Arid & 33-Kutum & $24.66-14.2$ & Silty Clay \\
\hline 12 & Wadi-Halfa & Arid & 3-Wadi-Halfa & $31.48-21.01$ & Poorly graded sand \\
\hline
\end{tabular}




\subsection{Climatic Data}

As discussed in the methodology, the climatic data were acquired using CLIMWAT 2. It was not possible to include dataset for all 12 sites; therefore, climatic data for a more central site, i.e., site 5, are presented in Table 2. Climatic data for all 12 sites are presented in Appendix A.

Table 2. CROPWAT 8 model climatic rainfall data and ETo values of Khartoum Station (site 5), Sudan.

\begin{tabular}{|c|c|c|c|c|c|c|c|c|c|}
\hline \multicolumn{2}{|c|}{ Station: Khartoum } & \multicolumn{3}{|c|}{ Altitude: $380 \mathrm{~m}$} & \multicolumn{2}{|c|}{ Latitude: $15.6^{\circ} \mathrm{N}$} & \multicolumn{3}{|c|}{ Longitude: $32.55^{\circ} \mathrm{E}$} \\
\hline Month & Min Temp & Max Temp & Humidity & Wind & Sun & Rad & ETo & Rain & Eff Rain \\
\hline & ${ }^{\circ} \mathrm{C}$ & ${ }^{\circ} \mathrm{C}$ & $\%$ & $\mathrm{~km} /$ day & hours & $\mathrm{MJ} / \mathrm{m}^{2} /$ day & $\mathrm{mm} /$ day & $\mathrm{mm}$ & $\mathrm{mm}$ \\
\hline January & 15.6 & 30.8 & 34 & 346 & 9.7 & 20 & 6.94 & 0 & 0 \\
\hline February & 17 & 33 & 25 & 389 & 10.7 & 23.1 & 8.64 & 0 & 0 \\
\hline March & 20.5 & 36.8 & 18 & 389 & 10.5 & 24.7 & 10.23 & 0 & 0 \\
\hline April & 23.6 & 40.1 & 16 & 346 & 10.9 & 26.2 & 10.76 & 0.4 & 0.4 \\
\hline May & 27.1 & 41.9 & 19 & 311 & 10.4 & 25.5 & 10.53 & 4 & 4 \\
\hline June & 27.3 & 41.3 & 26 & 346 & 9.8 & 24.2 & 10.6 & 5.4 & 5.4 \\
\hline July & 25.9 & 38.4 & 47 & 346 & 9 & 23.1 & 8.65 & 46.3 & 42.9 \\
\hline August & 25.3 & 37.3 & 55 & 346 & 8.7 & 22.7 & 7.77 & 75.2 & 66.2 \\
\hline September & 26 & 39.1 & 43 & 311 & 9.2 & 22.9 & 8.45 & 25.4 & 24.4 \\
\hline October & 25.5 & 39.3 & 32 & 268 & 9.2 & 21.4 & 8.2 & 4.8 & 4.8 \\
\hline November & 21 & 35.2 & 30 & 346 & 9.7 & 20.3 & 8.24 & 0.7 & 0.7 \\
\hline December & 17.1 & 31.8 & 35 & 346 & 9.9 & 19.6 & 7.06 & 0 & 0 \\
\hline Average & 22.7 & 37.1 & 32 & 341 & 9.8 & 22.8 & 8.84 & 162.2 & 148.6 \\
\hline
\end{tabular}

\subsection{Crop Data}

Sudan produces a variety of crops; however, wheat and sorghum are the most widely planted irrigated crops, as can be seen in Figure 11 [32]. Recently, it has been observed that cotton is being planted more due to the financial gains associated with it. Therefore, cotton, wheat, and sorghum were selected for this study. The crop data for all three crops under study are presented in Table 3.

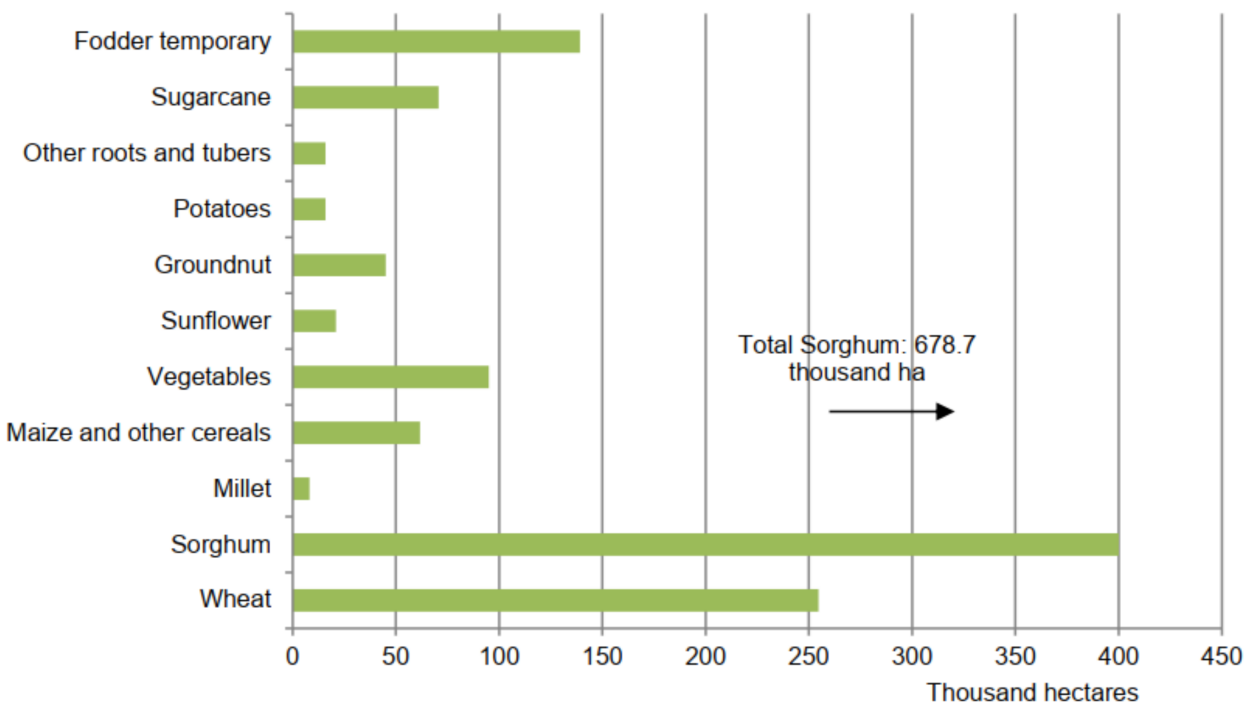

Figure 11. Main irrigated crops in Sudan [32]. 
Table 3. Crop data.

\begin{tabular}{|c|c|c|c|c|c|c|c|}
\hline \multirow{2}{*}{ Crop } & \multirow{2}{*}{$\begin{array}{c}\text { Planting and } \\
\text { Harvesting } \\
\text { Dates }\end{array}$} & \multirow{2}{*}{$\begin{array}{l}\text { Critical } \\
\text { Depletion } \\
\text { Fraction }\end{array}$} & \multirow{2}{*}{$\begin{array}{c}\text { Rooting } \\
\text { Depths (m) }\end{array}$} & \multicolumn{4}{|c|}{ Crop Growth Periods (Days) } \\
\hline & & & & Initial & Crop Development & Mid-Season & Late Season \\
\hline Wheat & 15 Nov-24 Mar & 0.55 & 0.30 & 30 & 30 & 40 & 30 \\
\hline Cotton & 1 Jul-11 Jan & 0.65 & 0.30 & 30 & 50 & 60 & 55 \\
\hline Sorghum & 1 Jun-1 Oct & 0.60 & 0.30 & 20 & 35 & 40 & 30 \\
\hline
\end{tabular}

The sowing season for cotton starts in July and continues until the middle of September, while it takes four to six months for a cotton seed to grow and mature into a plant with bolls ripe for picking [33]. Sorghum is sown between the beginning of May and the end of June and is harvested from October to December [32]. Wheat is sown in October and harvested in March [32]. Thus, the crop dates were taken following the dates provided by the FAO.

\subsection{Soil Data}

The types of soil differed according to site, as presented in Table 1. Using Table 1 and the FAO guidelines for soil description documents [26], the classification of each soil type was carried out and the FAO soil data files for soil type and class were used for each site.

\section{Results and Discussions}

Once all data were available, the crop water requirement was calculated, i.e., $\mathrm{ET}_{\mathrm{c}}$. Irrigation management can be improved with precise knowledge of the irrigation water requirements for the crop and irrigation time. Controlling the amount, timing, and rate of irrigation in an efficient and planned manner is the key to successful irrigation management. Therefore, it is imperative to calculate the water requirement and the irrigation schedule. It is important to note that the $\mathrm{K}_{\mathrm{c}}$ values of each crop varied with the development stage. Depending on the $\mathrm{K}_{\mathrm{c}}$ value, the crop water requirement will vary. The water requirements for all 3 crops at site 5 (Khartoum) are presented in Tables 4-6.

Table 4. Crop water requirements for wheat.

\begin{tabular}{lccccccc}
\hline Month & Decade & Stage & $\mathbf{K}_{\mathbf{c}}$ & $\mathbf{E T}_{\mathbf{c}}$ & $\mathbf{E T}_{\mathbf{c}}$ & Eff. Rain & Irr. Req. \\
\hline & & & $\mathrm{coeff}$ & $\mathrm{mm} / \mathrm{day}$ & $\mathrm{mm} / \mathrm{dec}$ & $\mathrm{mm} / \mathrm{dec}$ & $\mathrm{mm} / \mathrm{dec}$ \\
Nov. & 2 & Init & 0.30 & 2.5 & 15 & 0.10 & 15 \\
Nov. & 3 & Init & 0.30 & 2.38 & 23.8 & 0.10 & 23.70 \\
Dec. & 1 & Init & 0.30 & 2.22 & 22.2 & 0.10 & 22.10 \\
Dec. & 2 & Dev & 0.37 & 2.54 & 25.4 & 0 & 25.40 \\
Dec. & 3 & Dev & 0.67 & 4.68 & 51.5 & 0 & 51.50 \\
Jan. & 1 & Dev & 1 & 6.84 & 68.4 & 0 & 68.40 \\
Jan. & 2 & Mid & 1.22 & 8.25 & 82.5 & 0 & 82.50 \\
Jan. & 3 & Mid & 1.23 & 9.09 & 100 & 0 & 100 \\
Feb. & 1 & Mid & 1.23 & 9.95 & 99.5 & 0 & 99.50 \\
Feb. & 2 & Mid & 1.23 & 10.65 & 106.5 & 0 & 106.5 \\
Feb. & 3 & Late & 1.15 & 10.55 & 84.4 & 0 & 84.40 \\
Mar. & 1 & Late & 0.87 & 8.55 & 85.5 & 0 & 85.50 \\
Mar. & 2 & Late & 0.56 & 5.83 & 58.3 & 0 & 58.30 \\
Mar. & 3 & Late & 0.35 & 3.63 & 14.5 & 0 & 14.50 \\
& & Total & & & $\mathbf{8 3 7 . 3}$ & $\mathbf{0 . 3}$ & $\mathbf{8 3 7}$ \\
\hline
\end{tabular}

(Init = initial; Dev = development; Eff. Rain = effective rain; Irr. Req. = irrigation requirements; $\mathrm{ET}_{\mathrm{c}}=$ crop evapotranspiration; $\mathrm{mm} / \mathrm{dec}=$ millimeter per decade) . 
Table 5. Crop water requirements for cotton.

\begin{tabular}{cccccccc}
\hline Month & Decade & Stage & $\mathbf{K}_{\mathbf{c}}$ & $\mathbf{E T}_{\mathbf{c}}$ & $\mathbf{E T}_{\mathbf{c}}$ & Eff. Rain & Irr. Req. \\
\hline & & & coeff & $\mathrm{mm} /$ day & $\mathrm{mm} / \mathrm{dec}$ & $\mathrm{mm} / \mathrm{dec}$ & $\mathrm{mm} / \mathrm{dec}$ \\
Jul. & 1 & Init & 0.35 & 3.23 & 32.30 & 10.60 & 21.70 \\
Jul. & 2 & Init & 0.35 & 2.99 & 29.90 & 14.90 & 15 \\
Jul. & 3 & Dev & 0.35 & 2.91 & 32.10 & 17.30 & 14.70 \\
Aug. & 1 & Dev & 0.47 & 3.73 & 37.30 & 21.50 & 15.80 \\
Aug. & 2 & Dev & 0.64 & 4.94 & 49.40 & 25.10 & 24.30 \\
Aug. & 3 & Dev & 0.83 & 6.60 & 72.60 & 19.40 & 53.20 \\
Sep. & 1 & Dev & 1.02 & 8.46 & 84.60 & 12.10 & 72.50 \\
Sep. & 2 & Mid & 1.19 & 10.21 & 102.10 & 7.10 & 94.90 \\
Sep. & 3 & Mid & 1.24 & 10.49 & 104.90 & 5.30 & 99.60 \\
Oct. & 1 & Mid & 1.24 & 10.3 & 103 & 3.30 & 99.70 \\
Oct. & 2 & Mid & 1.24 & 10.19 & 101.90 & 0.90 & 101 \\
Oct. & 3 & Mid & 1.24 & 10.21 & 112.30 & 0.70 & 111.60 \\
Nov. & 1 & Mid & 1.24 & 10.31 & 103.10 & 0.60 & 102.50 \\
Nov. & 2 & Late & 1.24 & 10.32 & 103.20 & 0.10 & 103.10 \\
Nov. & 3 & Late & 1.15 & 9.14 & 91.40 & 0.10 & 91.30 \\
Dec. & 1 & Late & 1.05 & 7.77 & 77.70 & 0.10 & 77.60 \\
Dec. & 2 & Late & 0.95 & 6.6 & 66 & 0 & 66 \\
Dec. & 3 & Late & 0.84 & 5.83 & 64.20 & 0 & 64.20 \\
Jan. & 1 & Late & 0.73 & 5 & 50 & 0 & 50 \\
Jan. & 2 & Late & 0.67 & 4.53 & 4.5 & 0 & 4.50 \\
& & Total & & & $\mathbf{1 4 2 2 . 4}$ & $\mathbf{1 3 9 . 1}$ & $\mathbf{1 2 8 3 . 2}$ \\
\hline
\end{tabular}

(Init = initial; Dev = development; Eff. Rain = effective rain; Irr. Req. = irrigation requirements; ETc $=$ crop evapotranspiration; $\mathrm{mm} / \mathrm{dec}=$ millimeter per decade).

Table 6. Crop water requirements for sorghum.

\begin{tabular}{cccccccc}
\hline Month & Decade & Stage & $\mathbf{K}_{\mathbf{c}}$ & $\mathbf{E T}_{\mathbf{c}}$ & $\mathbf{E T}_{\mathbf{c}}$ & Eff. Rain & Irr. Req. \\
\hline & & & coeff & $\mathrm{mm} / \mathrm{day}$ & $\mathrm{mm} / \mathrm{dec}$ & $\mathrm{mm} / \mathrm{dec}$ & $\mathrm{mm} / \mathrm{dec}$ \\
Jul. & 1 & Init & 0.30 & 2.77 & 27.70 & 10.60 & 17.10 \\
Jul. & 2 & Init & 0.30 & 2.56 & 25.60 & 14.90 & 10.70 \\
Jul. & 3 & Dev & 0.43 & 3.54 & 39 & 17.30 & 21.60 \\
Aug. & 1 & Dev & 0.65 & 5.20 & 52 & 21.50 & 30.50 \\
Aug. & 2 & Dev & 0.86 & 6.61 & 66.10 & 25.10 & 41 \\
Aug. & 3 & Mid & 1.03 & 8.18 & 90 & 19.40 & 70.50 \\
Sep. & 1 & Mid & 1.04 & 8.65 & 86.50 & 12.10 & 74.40 \\
Sep. & 2 & Mid & 1.04 & 8.92 & 89.20 & 7.10 & 82.10 \\
Sep. & 3 & Mid & 1.04 & 8.80 & 88 & 5.30 & 82.70 \\
Oct. & 1 & Late & 1 & 8.28 & 82.80 & 3.30 & 79.50 \\
Oct. & 2 & Late & 0.85 & 6.99 & 69.90 & 0.90 & 69 \\
Oct. & 3 & Late & 0.69 & 5.68 & 62.50 & 0.70 & 61.80 \\
Nov. & 1 & Late & 0.59 & 4.92 & 9.80 & 0.10 & 9.80 \\
& & Total & & & $\mathbf{7 8 9}$ & $\mathbf{1 3 8 . 3}$ & $\mathbf{6 5 0 . 8}$ \\
\hline
\end{tabular}

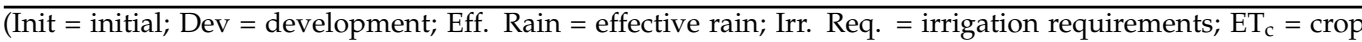
evapotranspiration; $\mathrm{mm} / \mathrm{dec}=$ millimeter per decade).

Tables 4-6 show that the cotton crop requires more water than wheat and sorghum. The selected site experiences little rain and the overall impact of the rain is not significant during the examined months. This highlights the need for a robust irrigation system for crops in the area to improve the yield and ensure high productivity. Figure 12 shows a comparison of $\mathrm{ET}_{\mathrm{c}}$, effective rain, and net irrigation requirement values for site 5 for 3 different crops during their lifetimes. This shows the lack of rain and higher water requirements for cotton and sorghum. 


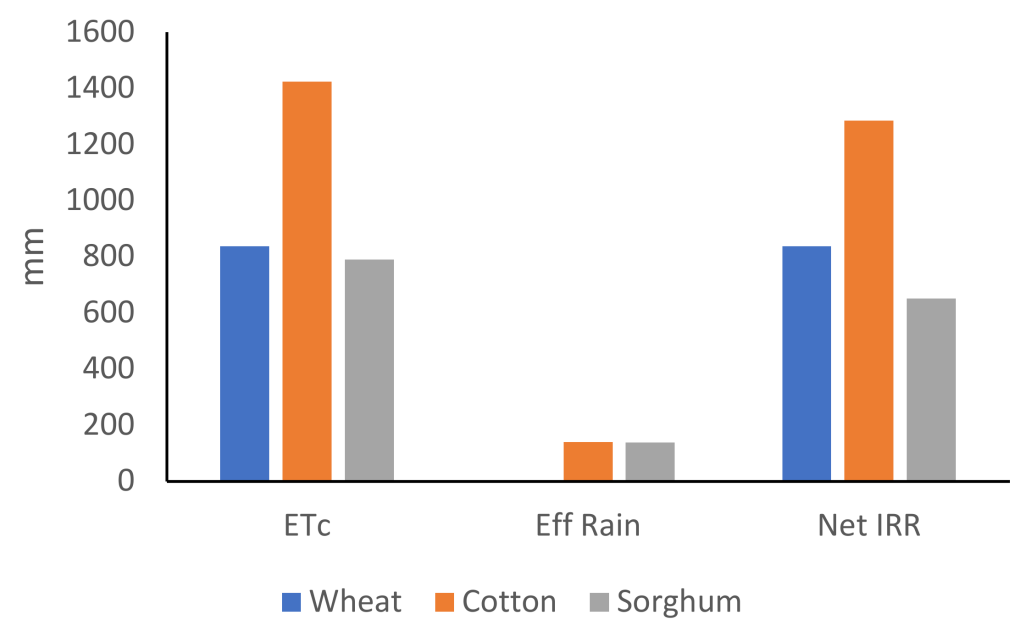

Figure 12. Comparison of $\mathrm{ET}_{\mathrm{c}}$ (crop evapotranspiration), effective rain (Eff. Rain), and net irrigation (Net IRR.) values for selected crops at site 5 .

Further to the knowledge of irrigation requirements, the irrigation schedule plays an important role in the crop yield. The crop yield can be increased with appropriate irrigation at the appropriate time. Tables 7-9 provide detailed irrigation water requirement data, including the net irrigation, gross irrigation, and flow rates required. The schedule is given in Figures 13-15. The figures show that wheat requires 21 irrigation cycles with a total of $837 \mathrm{~mm}$ of water, cotton requires 22 irrigation cycles with $1283 \mathrm{~mm}$ of water, and sorghum requires 14 irrigation cycles with $650.8 \mathrm{~mm}$ of water.

Table 7. Irrigation schedule for wheat.

\begin{tabular}{cclccccccccc}
\hline Date & Day & Stage & Rain & Ks & Eta & Depl & Net Irr & Deficit & Loss & Gr. Irr & Flow \\
\hline & & & $\mathrm{mm}$ & fact & $\%$ & $\%$ & $\mathrm{~mm}$ & $\mathrm{~mm}$ & $\mathrm{~mm}$ & $\mathrm{~mm}$ & $1 / \mathrm{s} / \mathrm{ha}$ \\
19-Nov & 5 & Init & 0 & 1 & 100 & 55 & 12.4 & 0 & 0 & 17.8 & 0.41 \\
26-Nov & 12 & Init & 0 & 1 & 100 & 58 & 16.7 & 0 & 0 & 23.9 & 0.39 \\
5-Dec & 21 & Init & 0 & 1 & 100 & 56 & 20.5 & 0 & 0 & 29.4 & 0.38 \\
16-Dec & 32 & Dev & 0 & 1 & 100 & 56 & 26.3 & 0 & 0 & 37.6 & 0.40 \\
25-Dec & 41 & Dev & 0 & 1 & 100 & 61 & 33.6 & 0 & 0 & 48 & 0.62 \\
1-Jan & 48 & Dev & 0 & 1 & 100 & 57 & 34.9 & 0 & 0 & 49.9 & 0.82 \\
07-Jan & 54 & Dev & 0 & 1 & 100 & 62 & 41.1 & 0 & 0 & 58.7 & 1.13 \\
13-Jan & 60 & Dev & 0 & 1 & 100 & 63 & 45.3 & 0 & 0 & 64.7 & 1.25 \\
18-Jan & 65 & Mid & 0 & 1 & 100 & 57 & 41.2 & 0 & 0 & 58.9 & 1.36 \\
23-Jan & 70 & Mid & 0 & 1 & 100 & 61 & 43.8 & 0 & 0 & 62.5 & 1.45 \\
28-Jan & 75 & Mid & 0 & 1 & 100 & 63 & 45.4 & 0 & 0 & 64.9 & 1.50 \\
2-Feb & 80 & Mid & 0 & 1 & 100 & 65 & 47.2 & 0 & 0 & 67.4 & 1.56 \\
6-Feb & 84 & Mid & 0 & 1 & 100 & 55 & 39.8 & 0 & 0 & 56.8 & 1.64 \\
10-Feb & 88 & Mid & 0 & 1 & 100 & 55 & 39.8 & 0 & 0 & 56.8 & 1.64 \\
14-Feb & 92 & Mid & 0 & 1 & 100 & 59 & 42.6 & 0 & 0 & 60.8 & 1.76 \\
18-Feb & 96 & Mid & 0 & 1 & 100 & 59 & 42.6 & 0 & 0 & 60.8 & 1.76 \\
22-Feb & 100 & Mid & 0 & 1 & 100 & 59 & 42.4 & 0 & 0 & 60.6 & 1.75 \\
26-Feb & 104 & End & 0 & 1 & 100 & 59 & 42.2 & 0 & 0 & 60.3 & 1.74 \\
3-Mar & 109 & End & 0 & 1 & 100 & 65 & 46.7 & 0 & 0 & 66.8 & 1.55 \\
09-Mar & 115 & End & 0 & 1 & 100 & 71 & 51.3 & 0 & 0 & 73.2 & 1.41 \\
18-Mar & 124 & End & 0 & 1 & 100 & 77 & 55.2 & 0 & 0 & 78.8 & 1.01 \\
\hline
\end{tabular}

(Init = initial; Dev = development; Ks = crop factor; Eta = actual crop evapotranspiration; Dep = Depletion; Net Irr $=$ net irrigation; $\mathrm{Gr}$. Irr = gross irrigation). 
Table 8. Irrigation schedule for cotton.

\begin{tabular}{cclccccccccc}
\hline Date & Day & Stage & Rain & Ks & Eta & Depl & Net Irr & Deficit & Loss & Gr. Irr & Flow \\
\hline & & & mm & fract. & $\%$ & $\%$ & $\mathrm{~mm}$ & $\mathrm{~mm}$ & $\mathrm{~mm}$ & $\mathrm{~mm}$ & $1 / \mathrm{s} / \mathrm{ha}$ \\
9-Jul & 9 & Init & 0 & 1 & 100 & 70 & 17.8 & 0 & 0 & 25.5 & 0.33 \\
31-Jul & 31 & Dev & 0 & 1 & 100 & 69 & 30.2 & 0 & 0 & 43.1 & 0.23 \\
21-Aug & 52 & Dev & 0 & 1 & 100 & 74 & 44.9 & 0 & 0 & 64.2 & 0.35 \\
31-Aug & 62 & Dev & 0 & 1 & 100 & 70 & 48.4 & 0 & 0 & 69.2 & 0.80 \\
8-Sep & 70 & Dev & 0 & 1 & 100 & 72 & 54.6 & 0 & 0 & 77.9 & 1.13 \\
14-Sep & 76 & Dev & 0 & 1 & 100 & 67 & 54.2 & 0 & 0 & 77.4 & 1.49 \\
20-Sep & 82 & Mid & 0 & 1 & 100 & 69 & 57.7 & 0 & 0 & 82.4 & 1.59 \\
26-Sep & 88 & Mid & 0 & 1 & 100 & 72 & 60.3 & 0 & 0 & 86.1 & 1.66 \\
2-Oct & 94 & Mid & 0 & 1 & 100 & 74 & 62.5 & 0 & 0 & 89.3 & 1.72 \\
08-Oct & 100 & Mid & 0 & 1 & 100 & 72 & 60.1 & 0 & 0 & 85.8 & 1.66 \\
14-Oct & 106 & Mid & 0 & 1 & 100 & 73 & 60.9 & 0 & 0 & 87 & 1.68 \\
20-Oct & 112 & Mid & 0 & 1 & 100 & 72 & 60.7 & 0 & 0 & 86.7 & 1.67 \\
26-Oct & 118 & Mid & 0 & 1 & 100 & 73 & 60.9 & 0 & 0 & 87.1 & 1.68 \\
1-Nov & 124 & Mid & 0 & 1 & 100 & 73 & 61.4 & 0 & 0 & 87.7 & 1.69 \\
7-Nov & 130 & Mid & 0.3 & 1 & 100 & 73 & 61.3 & 0 & 0 & 87.5 & 1.69 \\
13-Nov & 136 & Mid & 0.1 & 1 & 100 & 74 & 61.8 & 0 & 0 & 88.3 & 1.70 \\
19-Nov & 142 & End & 0 & 1 & 100 & 74 & 61.9 & 0 & 0 & 88.4 & 1.70 \\
26-Nov & 149 & End & 0 & 1 & 100 & 78 & 65.1 & 0 & 0 & 93.1 & 1.54 \\
4-Dec & 157 & End & 0 & 1 & 100 & 80 & 67.6 & 0 & 0 & 96.6 & 1.40 \\
13-Dec & 166 & End & 0 & 1 & 100 & 79 & 66.4 & 0 & 0 & 94.8 & 1.22 \\
24-Dec & 177 & End & 0 & 1 & 100 & 83 & 69.5 & 0 & 0 & 99.3 & 1.04 \\
7-Jan & 191 & End & 0 & 1 & 100 & 90 & 75.8 & 0 & 0 & 108.3 & 0.90 \\
\hline
\end{tabular}

(Init = initial; Dev = development; Ks = crop factor; Eta = actual crop evapotranspiration; Dep = Depletion; Net Irr $=$ net irrigation; Gr. Irr = gross irrigation).

Table 9. Irrigation schedule for sorghum.

\begin{tabular}{cccccccccccc}
\hline Date & Day & Stage & Rain & Ks & Eta & Depl & Net Irr & Deficit & Loss & Gr. Irr & Flow \\
\hline & & & mm & fract. & $\%$ & $\%$ & $\mathrm{~mm}$ & $\mathrm{~mm}$ & $\mathrm{~mm}$ & $\mathrm{~mm}$ & $\mathrm{~L} / \mathrm{s} / \mathrm{ha}$ \\
11-Jul & 11 & Init & 0 & 1 & 100 & 61 & 19.1 & 0 & 0 & 27.3 & 0.29 \\
31-Jul & 31 & Dev & 0 & 1 & 100 & 59 & 32.5 & 0 & 0 & 46.4 & 0.27 \\
12-Aug & 43 & Dev & 0 & 1 & 100 & 61 & 42.7 & 0 & 0 & 60.9 & 0.59 \\
21-Aug & 52 & Dev & 0 & 1 & 100 & 58 & 46.7 & 0 & 0 & 66.7 & 0.86 \\
29-Aug & 60 & Mid & 0 & 1 & 100 & 55 & 46.2 & 0 & 0 & 66.1 & 0.96 \\
4-Sep & 66 & Mid & 0 & 1 & 100 & 53 & 44.4 & 0 & 0 & 63.4 & 1.22 \\
10-Sep & 72 & Mid & 0 & 1 & 100 & 54 & 45.3 & 0 & 0 & 64.8 & 1.25 \\
16-Sep & 78 & Mid & 0 & 1 & 100 & 59 & 50 & 0 & 0 & 71.4 & 1.38 \\
21-Sep & 83 & Mid & 0 & 1 & 100 & 53 & 44.5 & 0 & 0 & 63.5 & 1.47 \\
27-Sep & 89 & Mid & 2.6 & 1 & 100 & 57 & 47.5 & 0 & 0 & 67.9 & 1.31 \\
2-Oct & 94 & Mid & 0 & 1 & 100 & 51 & 43 & 0 & 0 & 61.4 & 1.42 \\
8-Oct & 100 & End & 0 & 1 & 100 & 57 & 48 & 0 & 0 & 68.6 & 1.32 \\
16-Oct & 108 & End & 0 & 1 & 100 & 69 & 58.1 & 0 & 0 & 82.9 & 1.20 \\
26-Oct & 118 & End & 0 & 1 & 100 & 73 & 61.7 & 0 & 0 & 88.2 & 1.02 \\
\hline
\end{tabular}

(Init = initial; Dev = development; Ks = crop factor; Eta = actual crop evapotranspiration; Dep = Depletion; Net Irr $=$ net irrigation; Gr. Irr = gross irrigation).

Figure 16 shows that in all cases cotton requires the highest level of water, although the differences between the irrigation water rates for wheat and cotton vary significantly according to site. This is due to a multitude of factors, particularly the effective rain rate, crop characteristics, and soil characteristics. These factors play vital roles, although the ability of soil to retain moisture and effective rain plays a significant role in this variation. It is interesting that the areas in the northern region require significantly higher levels of water, except for site 3 . Site 3 is located close to the red sea and the climatic conditions are comparatively less harsh. Site 4 , which is also located near the red sea, tends to require a higher amount of water due to higher temperatures. This points out the importance of temperature, which plays a vital role in evapotranspiration. A comparison with the reference evapotranspiration rate is shown in Figure 17, which reveals that the northern regions have higher evapotranspiration as compared to the southern regions. 


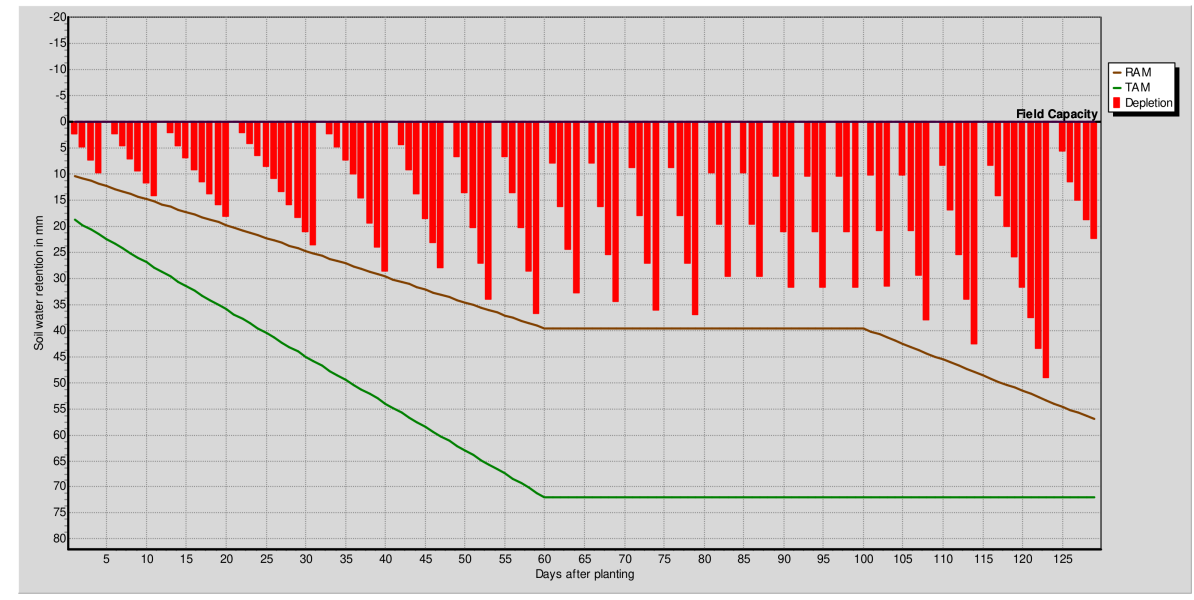

Figure 13. Irrigation schedule for wheat at site 5 ( $x$-axis shows days after planting and $y$-axis shows soil water retention in $\mathrm{mm})$. TAM = total available moisture; $\mathrm{RAM}=$ readily available moisture.

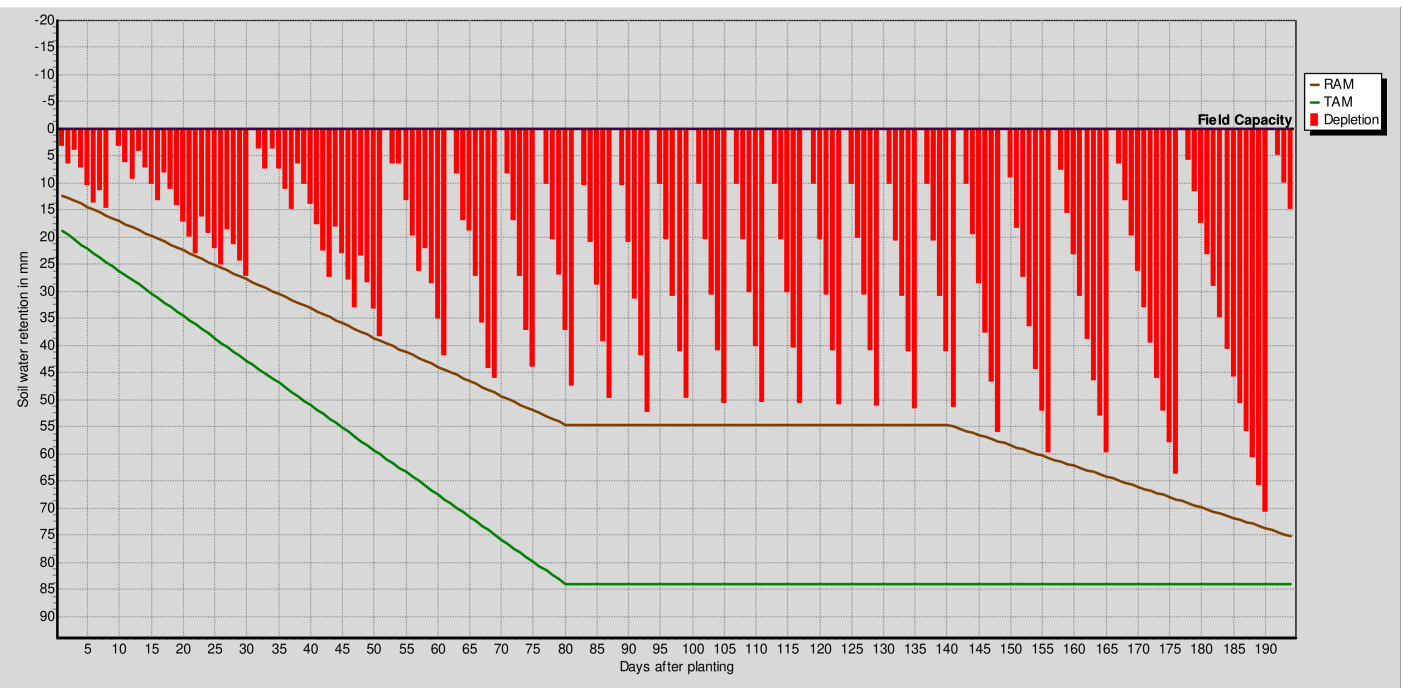

Figure 14. Irrigation schedule for cotton at site 5 ( $x$-axis shows days after planting and $y$-axis shows soil water retention in $\mathrm{mm}) . \mathrm{TAM}=$ total available moisture; $\mathrm{RAM}=$ readily available moisture.

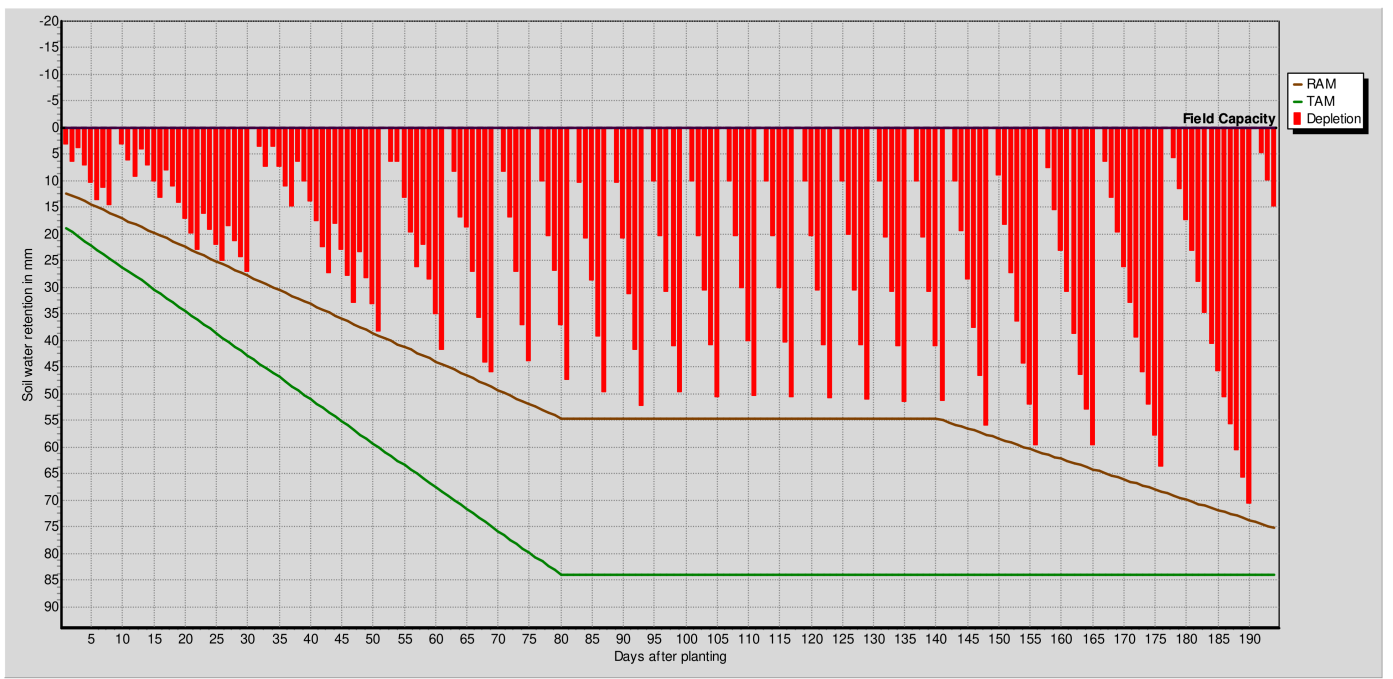

Figure 15. Irrigation schedule for sorghum at site 5 ( $x$-axis shows days after planting and $y$-axis shows soil water retention in $\mathrm{mm}) . \mathrm{TAM}=$ total available moisture; $\mathrm{RAM}=$ readily available moisture. 
Figure 16 presents irrigation water requirements for the three crops at all 12 sites.

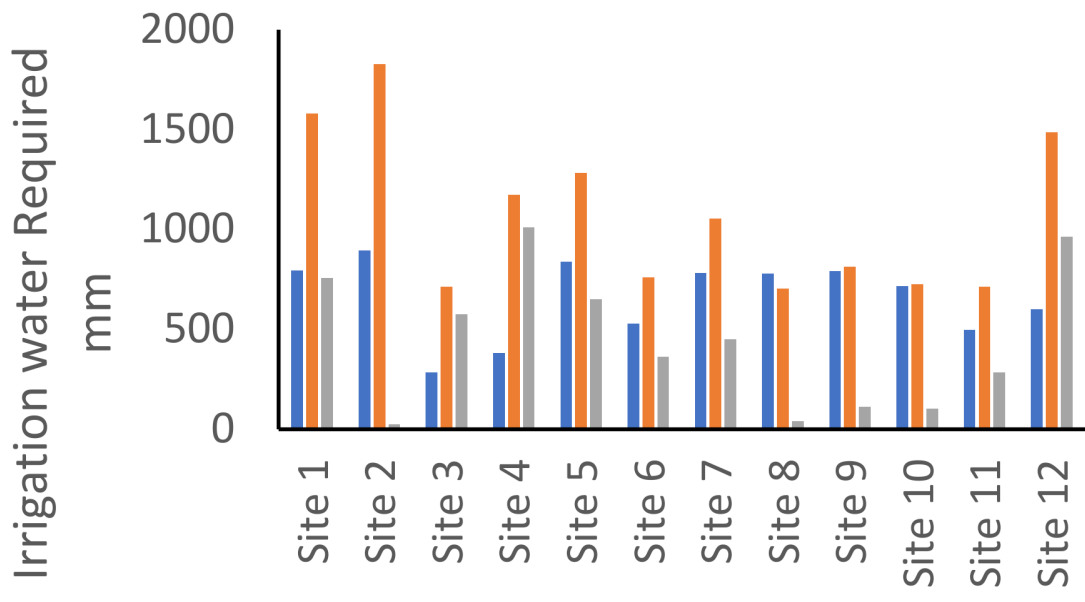

Wheat Cotton Sorghum

Figure 16. Irrigation water amounts required at all 12 sites.

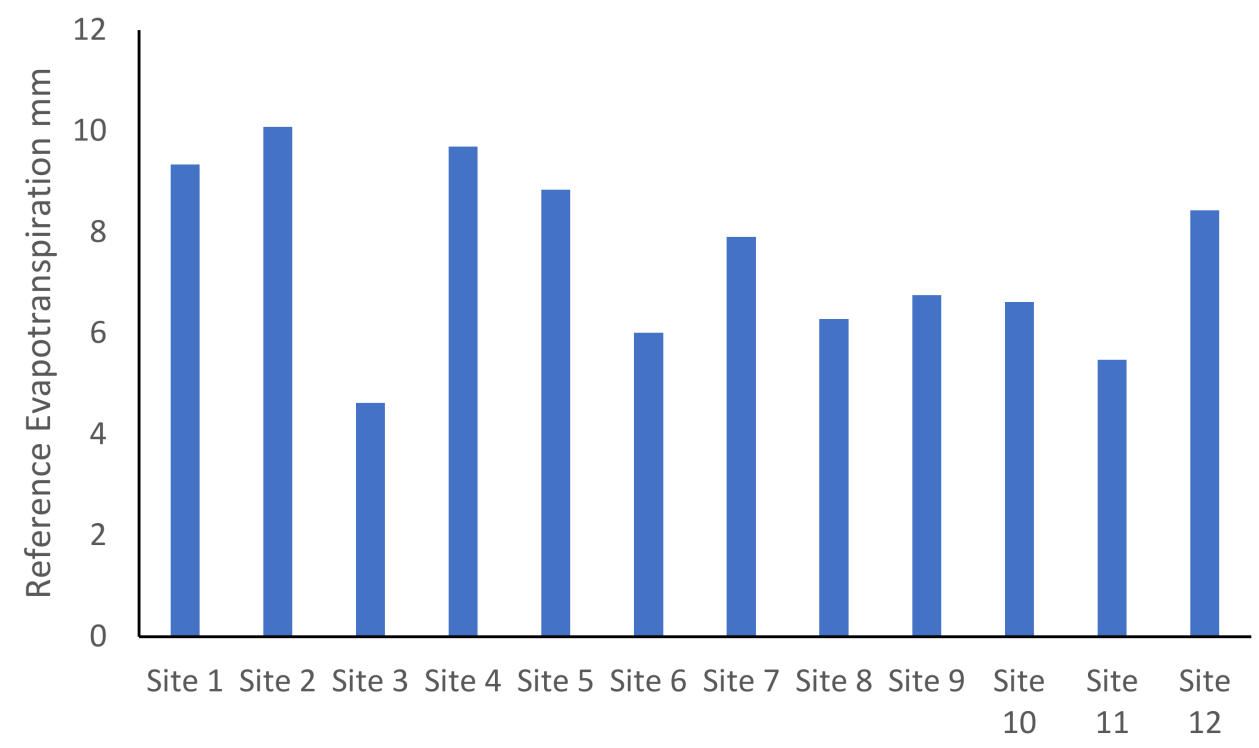

Figure 17. $\mathrm{ET}_{0}$ values for selected sites.

The comparison of the number of irrigation cycles required at different sites with different soil types presents interesting results. With more sandy soil types, the number of irrigation cycles tends to be higher, whereas soil types with higher amounts of clay tend to require lower numbers of irrigation cycles. This can be observed from Figure 18, where the southern sites tend to require lower numbers of irrigation cycles (as low as 2). It is interesting to note that although site 3 has the lowest irrigation water requirement, this does not necessarily mean the number of irrigation cycles will be the lowest. Therefore, a comprehensive understanding based on scientific studies such as this is essential for successful irrigation management. 


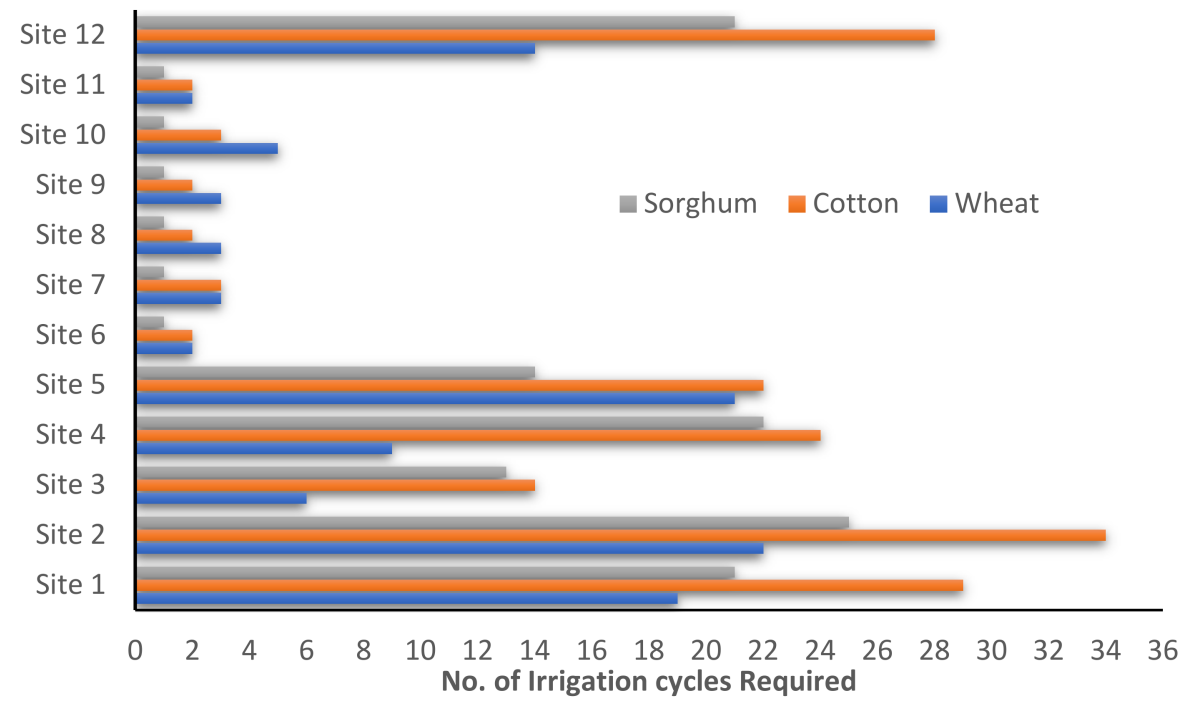

Figure 18. Number of irrigation cycles required at different sites for different crops.

The higher crop water requirements and numbers of irrigation cycles tend to mean that higher amounts of energy will be required to pump the water and more frequent operation of the pump will be required. The crop water requirement data for all 12 sites were used to calculate the amount of energy required by each crop at each site and are given in Figure 19. It was assumed that the water will need to be lifted to a height of $40 \mathrm{~m}$, with a pump efficiency rate of $80 \%$.

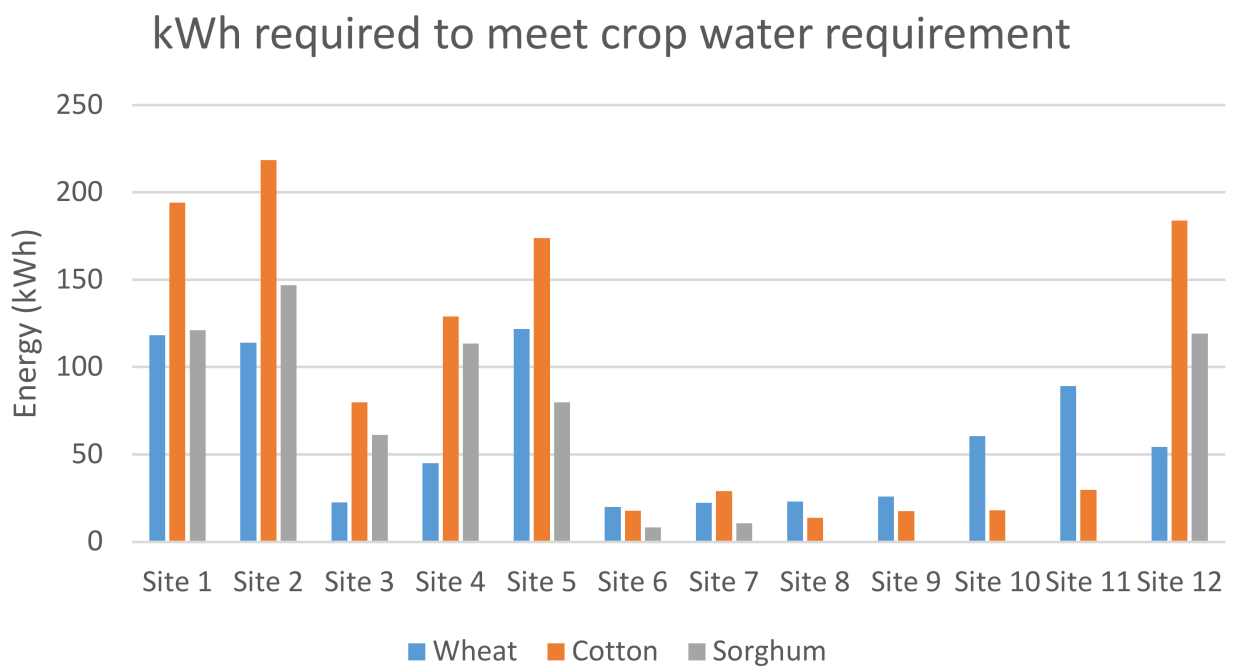

Figure 19. Energy required at each site to meet crop water requirements.

This study has analyzed a number of different sites in terms of the water required for different crops and calculated the amount of energy required to pump this water. The results can be used as a benchmark to compare per hectare crop water requirements in different areas of Sudan and the energy required to aid in the design of the pump size. Overall, arid areas tend to have higher water requirements for the same crop as compared to semi-arid areas. However, variations in crop water requirements in different regions for different crops were observed due to rain patterns. Cotton, being a crop that requires high amount of water, did not require more water at sites 6 to 11. This was mainly due to the weather and rain patterns. Sorghum is a weather-tolerant crop, although at some sites it required higher amounts of water as compared to wheat. These data are important to determine the impacts of climate change and particularly to develop resilient crops that are resistant to stresses resulting from climate change and other factors. 
The crop water requirement results were used to calculate the electricity needed $(\mathrm{kWh})$ by water pumps in different areas. The energy requirements at different sites show that the sites located further north tend to have higher energy demands and are potential candidates for renewable energy development. Higher energy demands warrant the use of hybrid energy, which can be beneficial in agricultural applications, helping to reduce energy poverty and improve yields, and consequently helping to reduce poverty and improve food security. Some studies have developed renewable energy systems for irrigation purposes, although these studies did not adopt the detailed approach of determining the energy demands according to the crop water requirements [34,35]. A systematic approach to determining the energy demands of crops has been presented herein. The results from this study will be used as a stepping stone to develop feasible renewable energy system options for the different sites in Sudan. This study will pave the way for the integration of future renewable energy sources into the agricultural sector, which will help in reducing pollution by cutting carbon emissions and increasing savings for farmers by reducing their expenses for fuels.

\section{Conclusions}

This study has presented a comparison of crop water requirements for three different crops at 12 different sites in Sudan. Moreover, the amounts of energy required for all sites to meet the water requirement have been calculated. The comparison suggested that the areas that are arid and located in the north require higher amounts of water and have less effective rainfall. However, the significance of temperature is higher for the sites located near the red sea. The results suggest that depending on the climatic conditions, the crops requiring high amounts of water in arid regions might not necessarily be the ones requiring the highest amounts of energy. The depth of the borehole and other climatic conditions play bigger roles in the energy requirements. The data for crop water requirements have been translated into energy requirements according to the different borehole depths at each site. The northern regions tend to require higher amounts of energy to meet the crop water requirements but at the same time they tend to have longer daylight hours and higher winds, making them suitable candidates for hybrid energy generation.

Thus, the use of tools such as CLIMWAT and CROPWAT can be beneficial in planning and managing irrigation systems with a significant degree of confidence. The use of these tools will not only be beneficial by providing information regarding the crop water requirements but will also provide information about when and how much water is needed for the optimum development of the crops. These tools can be beneficial not only in terms of increasing crop yields but also in planning the use of resources, such as the energy required to supply the water required for crops. Future studies will include the development of hybrid renewable energy systems for the different areas in Sudan using the energy requirements calculated in this study. Specifically, the use of hybrid renewable energy (e.g., solar PV and wind) is particularly advantageous because there are no operational GHG emissions, which have been mainly attributed to climate change and have produced unprecedented consequences in recent time. Additionally, the costs of renewable energy conversion technologies have decreased rapidly in recent years. Other future studies will include an exploration of the techno-economic feasibility of different renewable energy systems to meet energy demands and crop water requirements for the sites and crops presented in this study.

Author Contributions: Conceptualization, M.I. and Z.A.K.; methodology, M.I., Z.A.K. and A.O.A.; software, Z.A.K.; validation, M.I., Z.A.K., J.U., S.A. and O.E.D.; formal analysis, Z.A.K. and A.O.A.; investigation, Z.A.K., J.U. and S.A.; resources, M.I., O.E.D. and J.U.; data curation, Z.A.K. and S.A.; writing-original draft preparation, Z.A.K.; writing-review and editing, M.I., A.O.A., O.E.D., J.U., and Z.A.K.; visualization, Z.A.K.; supervision, M.I.; project administration, M.I.; funding acquisition, M.I., A.O.A. and O.E.D. All authors have read and agreed to the published version of the manuscript. 
Funding: This research was funded by Innovate UK and Academy of Medical Sciences, grant numbers 60558 and 62327, under the Global Challenge research fund. The APC was funded by grant number 60558 .

Institutional Review Board Statement: Not applicable.

Informed Consent Statement: Not applicable.

Data Availability Statement: Additional results and data are presented in Appendix A.

Conflicts of Interest: The authors declare no conflict of interest. The funders had no role in the design of the study; in the collection, analyses, or interpretation of data; in the writing of the manuscript, or in the decision to publish the results.

Appendix A

Table A1. Climate data for 12 selected sites.

\begin{tabular}{|c|c|c|c|c|c|c|c|c|c|}
\hline \multicolumn{10}{|c|}{ Site 1} \\
\hline Month & Min Temp & Max Temp & Humidity & Wind & Sun & Rad & ETo & Rain & Eff Rain \\
\hline & ${ }^{\circ} \mathrm{C}$ & ${ }^{\circ} \mathrm{C}$ & $\%$ & $\mathrm{~km} /$ day & hours & $\mathrm{MJ} / \mathrm{m}^{2} /$ day & $\mathrm{mm} /$ day & $\mathrm{mm}$ & $\mathrm{mm}$ \\
\hline January & 11.9 & 28 & 34 & 389 & 8.9 & 18.1 & 6.55 & 0 & 0 \\
\hline February & 13.5 & 30.5 & 26 & 423 & 9.5 & 20.8 & 8.09 & 0 & 0 \\
\hline March & 17.3 & 34.7 & 20 & 389 & 9.5 & 22.7 & 9.39 & 0 & 0 \\
\hline April & 21.5 & 38.8 & 19 & 389 & 9.9 & 24.6 & 10.81 & 0 & 0 \\
\hline May & 25.1 & 42 & 17 & 389 & 9.9 & 24.8 & 11.8 & 0.1 & 0.1 \\
\hline June & 26.9 & 43.4 & 19 & 346 & 9.4 & 23.9 & 11.33 & 0.1 & 0.1 \\
\hline July & 27 & 41.9 & 27 & 311 & 9.7 & 24.4 & 10.2 & 7.7 & 7.6 \\
\hline August & 27.1 & 41.4 & 38 & 311 & 9 & 23.2 & 9.27 & 11.4 & 11.2 \\
\hline September & 27.1 & 42.1 & 24 & 346 & 8.9 & 22.2 & 10.49 & 1.1 & 1.1 \\
\hline October & 23.8 & 39.2 & 26 & 346 & 9.3 & 21 & 9.54 & 0.3 & 0.3 \\
\hline November & 18 & 33.2 & 34 & 389 & 9.4 & 19.2 & 7.89 & 0 & 0 \\
\hline December & 13.8 & 29.4 & 35 & 389 & 9.3 & 17.9 & 6.75 & 0 & 0 \\
\hline Average & 21.1 & 37 & 27 & 368 & 9.4 & 21.9 & 9.34 & 20.7 & 20.4 \\
\hline \multicolumn{10}{|c|}{ Site 2} \\
\hline Month & Min Temp & Max Temp & Humidity & Wind & Sun & Rad & ETo & Rain & Eff Rain \\
\hline & ${ }^{\circ} \mathrm{C}$ & ${ }^{\circ} \mathrm{C}$ & $\%$ & $\mathrm{~km} /$ day & hours & $\mathrm{MJ} / \mathrm{m}^{2} /$ day & $\mathrm{mm} /$ day & $\mathrm{mm}$ & $\mathrm{mm}$ \\
\hline January & 12.5 & 28.1 & 33 & 501 & 8.9 & 17.9 & 7.37 & 0.2 & 0.2 \\
\hline February & 13.8 & 30.4 & 25 & 501 & 9.3 & 20.3 & 8.75 & 0 & 0 \\
\hline March & 17.3 & 34.6 & 20 & 467 & 9.8 & 23.1 & 10.27 & 0 & 0 \\
\hline April & 21 & 38.7 & 18 & 423 & 10.5 & 25.4 & 11.33 & 0.1 & 0.1 \\
\hline May & 25 & 41.9 & 17 & 346 & 10.5 & 25.7 & 11.17 & 0.2 & 0.2 \\
\hline June & 27.2 & 43.5 & 16 & 346 & 10.7 & 25.9 & 11.7 & 0.1 & 0.1 \\
\hline July & 26.9 & 42.1 & 23 & 346 & 9.9 & 24.6 & 10.97 & 5.1 & 5.1 \\
\hline August & 27.2 & 41.7 & 30 & 346 & 9.5 & 23.9 & 10.34 & 6 & 5.9 \\
\hline September & 27.3 & 42.4 & 21 & 423 & 9.3 & 22.7 & 11.98 & 0.7 & 0.7 \\
\hline October & 23.7 & 39.2 & 24 & 423 & 9.8 & 21.4 & 10.68 & 0.1 & 0.1 \\
\hline November & 18.9 & 33.3 & 33 & 501 & 9.2 & 18.6 & 8.94 & 0.1 & 0.1 \\
\hline December & 14.4 & 29.4 & 36 & 501 & 8.9 & 17.2 & 7.45 & 0 & 0 \\
\hline Average & 21.3 & 37.1 & 25 & 427 & 9.7 & 22.2 & 10.08 & 12.6 & 12.5 \\
\hline \multicolumn{10}{|c|}{ Site 3} \\
\hline Month & Min Temp & Max Temp & Humidity & Wind & Sun & $\operatorname{Rad}$ & ETo & Rain & Eff Rain \\
\hline & ${ }^{\circ} \mathrm{C}$ & ${ }^{\circ} \mathrm{C}$ & $\%$ & $\mathrm{~km} /$ day & hours & $\mathrm{MJ} / \mathrm{m}^{2} /$ day & $\mathrm{mm} /$ day & $\mathrm{mm}$ & $\mathrm{mm}$ \\
\hline January & 17.2 & 26.1 & 87 & 259 & 6.2 & 14.1 & 2.63 & 1 & 1 \\
\hline February & 17.2 & 26.7 & 86 & 259 & 7.4 & 17.3 & 3.18 & 2 & 2 \\
\hline March & 17.8 & 28.3 & 84 & 242 & 8.4 & 20.8 & 3.96 & 0 & 0 \\
\hline April & 18.9 & 31.1 & 81 & 242 & 9.3 & 23.5 & 4.84 & 0 & 0 \\
\hline May & 21.7 & 34.4 & 78 & 216 & 9.7 & 24.6 & 5.6 & 2 & 2 \\
\hline June & 22.8 & 37.8 & 73 & 190 & 10 & 25 & 6.24 & 0 & 0 \\
\hline
\end{tabular}


Table A1. Cont.

\begin{tabular}{|c|c|c|c|c|c|c|c|c|c|}
\hline July & 25 & 38.9 & 75 & 216 & 10.1 & 25 & 6.5 & 0 & 0 \\
\hline August & 26.1 & 38.9 & 70 & 216 & 9.7 & 24.1 & 6.64 & 0 & 0 \\
\hline September & 24.4 & 37.2 & 76 & 190 & 9 & 22 & 5.64 & 0 & 0 \\
\hline October & 22.2 & 33.3 & 92 & 190 & 8.2 & 18.9 & 3.96 & 9 & 8.9 \\
\hline November & 21.1 & 30.5 & 85 & 242 & 7 & 15.4 & 3.36 & 12 & 11.8 \\
\hline December & 18.9 & 27.2 & 82 & 242 & 6.5 & 13.9 & 2.91 & 11 & 10.8 \\
\hline Average & 21.1 & 32.5 & 81 & 225 & 8.5 & 20.4 & 4.62 & 37 & 36.4 \\
\hline \multicolumn{10}{|c|}{ Site 4} \\
\hline Month & Min Temp & Max Temp & Humidity & Wind & Sun & $\operatorname{Rad}$ & ETo & Rain & Eff Rain \\
\hline & ${ }^{\circ} \mathrm{C}$ & ${ }^{\circ} \mathrm{C}$ & $\%$ & $\mathrm{~km} /$ day & hours & $\mathrm{MJ} / \mathrm{m}^{2} /$ day & $\mathrm{mm} /$ day & $\mathrm{mm}$ & $\mathrm{mm}$ \\
\hline January & 20 & 28.2 & 71 & 346 & 5.3 & 13.6 & 3.97 & 15 & 14.6 \\
\hline February & 19.7 & 28.7 & 68 & 268 & 5.2 & 14.9 & 4.08 & 3 & 3 \\
\hline March & 20.9 & 30.9 & 66 & 268 & 7.1 & 19.3 & 5.04 & 0 & 0 \\
\hline April & 22 & 33.7 & 62 & 268 & 8.8 & 22.9 & 6.21 & 1 & 1 \\
\hline May & 23.1 & 37.7 & 54 & 268 & 9.6 & 24.4 & 7.42 & 2 & 2 \\
\hline June & 25.1 & 42.3 & 41 & 311 & 10 & 24.8 & 9.45 & 0 & 0 \\
\hline July & 28 & 42.9 & 36 & 467 & 9.7 & 24.3 & 11.87 & 6 & 5.9 \\
\hline August & 28.3 & 42.4 & 39 & 423 & 9.3 & 23.7 & 11.01 & 6 & 5.9 \\
\hline September & 26.2 & 41.3 & 45 & 268 & 9 & 22.3 & 8.24 & 0 & 0 \\
\hline October & 25.3 & 36.8 & 60 & 346 & 8.2 & 19.5 & 6.8 & 6 & 5.9 \\
\hline November & 23.6 & 33.1 & 65 & 311 & 7.5 & 16.8 & 5.24 & 19 & 18.4 \\
\hline December & 21.2 & 29.8 & 69 & 311 & 6.3 & 14.4 & 4.23 & 15 & 14.6 \\
\hline Average & 23.6 & 35.6 & 56 & 321 & 8 & 20.1 & 6.96 & 73 & 71.5 \\
\hline \multicolumn{10}{|c|}{ Site 5} \\
\hline Month & Min Temp & Max Temp & Humidity & Wind & Sun & Rad & ETo & Rain & Eff Rain \\
\hline & ${ }^{\circ} \mathrm{C}$ & ${ }^{\circ} \mathrm{C}$ & $\%$ & $\mathrm{~km} /$ day & hours & $\mathrm{MJ} / \mathrm{m}^{2} /$ day & $\mathrm{mm} /$ day & $\mathrm{mm}$ & $\mathrm{mm}$ \\
\hline January & 15.6 & 30.8 & 34 & 346 & 9.7 & 20 & 6.94 & 0 & 0 \\
\hline February & 17 & 33 & 25 & 389 & 10.7 & 23.1 & 8.64 & 0 & 0 \\
\hline March & 20.5 & 36.8 & 18 & 389 & 10.5 & 24.7 & 10.23 & 0 & 0 \\
\hline April & 23.6 & 40.1 & 16 & 346 & 10.9 & 26.2 & 10.76 & 0.4 & 0.4 \\
\hline May & 27.1 & 41.9 & 19 & 311 & 10.4 & 25.5 & 10.53 & 4 & 4 \\
\hline June & 27.3 & 41.3 & 26 & 346 & 9.8 & 24.2 & 10.6 & 5.4 & 5.4 \\
\hline July & 25.9 & 38.4 & 47 & 346 & 9 & 23.1 & 8.65 & 46.3 & 42.9 \\
\hline August & 25.3 & 37.3 & 55 & 346 & 8.7 & 22.7 & 7.77 & 75.2 & 66.2 \\
\hline September & 26 & 39.1 & 43 & 311 & 9.2 & 22.9 & 8.45 & 25.4 & 24.4 \\
\hline October & 25.5 & 39.3 & 32 & 268 & 9.2 & 21.4 & 8.2 & 4.8 & 4.8 \\
\hline November & 21 & 35.2 & 30 & 346 & 9.7 & 20.3 & 8.24 & 0.7 & 0.7 \\
\hline December & 17.1 & 31.8 & 35 & 346 & 9.9 & 19.6 & 7.06 & 0 & 0 \\
\hline Average & 22.7 & 37.1 & 32 & 341 & 9.8 & 22.8 & 8.84 & 162.2 & 148.6 \\
\hline \multicolumn{10}{|c|}{ Site 6} \\
\hline Month & Min Temp & Max Temp & Humidity & Wind & Sun & Rad & ETo & Rain & Eff Rain \\
\hline & ${ }^{\circ} \mathrm{C}$ & ${ }^{\circ} \mathrm{C}$ & $\%$ & $\mathrm{~km} /$ day & hours & $\mathrm{MJ} / \mathrm{m}^{2} /$ day & $\mathrm{mm} /$ day & $\mathrm{mm}$ & $\mathrm{mm}$ \\
\hline January & 16.5 & 33.7 & 48 & 156 & 8.8 & 18.8 & 4.81 & 0 & 0 \\
\hline February & 17.2 & 35.2 & 43 & 156 & 9.4 & 21.3 & 5.48 & 0 & 0 \\
\hline March & 20.1 & 38.3 & 40 & 156 & 9.3 & 22.9 & 6.27 & 0.3 & 0.3 \\
\hline April & 23 & 40.8 & 37 & 156 & 9.6 & 24.3 & 7 & 2 & 2 \\
\hline May & 25.8 & 41.6 & 39 & 156 & 9.4 & 23.9 & 7.18 & 8.8 & 8.7 \\
\hline June & 25.7 & 39.8 & 42 & 190 & 8.8 & 22.8 & 7.31 & 27.9 & 26.7 \\
\hline July & 23.9 & 36.1 & 57 & 233 & 7.5 & 20.8 & 6.41 & 76 & 66.8 \\
\hline August & 23.4 & 34.9 & 63 & 233 & 7.5 & 20.8 & 5.9 & 85 & 73.4 \\
\hline September & 24 & 36.8 & 55 & 156 & 8.9 & 22.5 & 5.95 & 40.5 & 37.9 \\
\hline October & 24.3 & 38.7 & 44 & 112 & 9.3 & 21.6 & 5.6 & 9.9 & 9.7 \\
\hline November & 21.4 & 37 & 47 & 156 & 9.1 & 19.5 & 5.46 & 0.8 & 0.8 \\
\hline December & 17.9 & 34.4 & 52 & 156 & 8.8 & 18.3 & 4.78 & 0 & 0 \\
\hline Average & 21.9 & 37.3 & 47 & 168 & 8.9 & 21.5 & 6.01 & 251.2 & 226.2 \\
\hline
\end{tabular}


Table A1. Cont.

\begin{tabular}{|c|c|c|c|c|c|c|c|c|c|}
\hline \multicolumn{10}{|c|}{ Site 7} \\
\hline Month & Min Temp & Max Temp & Humidity & Wind & Sun & Rad & ETo & Rain & Eff Rain \\
\hline & ${ }^{\circ} \mathrm{C}$ & ${ }^{\circ} \mathrm{C}$ & $\%$ & $\mathrm{~km} /$ day & hours & $\mathrm{MJ} / \mathrm{m}^{2} /$ day & $\mathrm{mm} /$ day & $\mathrm{mm}$ & $\mathrm{mm}$ \\
\hline January & 16.3 & 31.3 & 34 & 311 & 8.9 & 19.4 & 6.73 & 0 & 0 \\
\hline February & 17.7 & 33.2 & 28 & 346 & 9.3 & 21.5 & 8 & 0 & 0 \\
\hline March & 20 & 37.3 & 24 & 346 & 9.5 & 23.4 & 9.32 & 0.1 & 0.1 \\
\hline April & 23.4 & 40.1 & 23 & 346 & 9.7 & 24.4 & 10.26 & 0.1 & 0.1 \\
\hline May & 24.3 & 41.2 & 28 & 311 & 9.6 & 24.1 & 9.77 & 5.8 & 5.7 \\
\hline June & 25.3 & 39.5 & 39 & 311 & 9 & 22.9 & 8.88 & 22.1 & 21.3 \\
\hline July & 25 & 36.2 & 53 & 311 & 7.7 & 21 & 7.27 & 65.8 & 58.9 \\
\hline August & 23.6 & 34.6 & 61 & 268 & 7.4 & 20.7 & 6.21 & 99.6 & 83.7 \\
\hline September & 23.9 & 36.5 & 53 & 268 & 8.3 & 21.7 & 6.89 & 38.1 & 35.8 \\
\hline October & 24.3 & 38.1 & 42 & 233 & 8.8 & 21.1 & 7.12 & 5.2 & 5.2 \\
\hline November & 21 & 35.4 & 32 & 311 & 9.2 & 20.1 & 7.75 & 0.4 & 0.4 \\
\hline December & 17.9 & 32.2 & 37 & 311 & 9.1 & 19.1 & 6.75 & 0 & 0 \\
\hline Average & 21.9 & 36.3 & 38 & 306 & 8.9 & 21.6 & 7.91 & 237.2 & 211.2 \\
\hline \multicolumn{10}{|c|}{ Site 8} \\
\hline Month & Min Temp & Max Temp & Humidity & Wind & Sun & Rad & ETo & Rain & Eff Rain \\
\hline & ${ }^{\circ} \mathrm{C}$ & ${ }^{\circ} \mathrm{C}$ & $\%$ & $\mathrm{~km} /$ day & hours & $\mathrm{MJ} / \mathrm{m}^{2} /$ day & $\mathrm{mm} /$ day & $\mathrm{mm}$ & $\mathrm{mm}$ \\
\hline January & 17.4 & 34.4 & 23 & 268 & 9.4 & 20.8 & 7.32 & 0 & 0 \\
\hline February & 19.3 & 36.1 & 20 & 268 & 9.6 & 22.6 & 8.01 & 0 & 0 \\
\hline March & 22 & 38.9 & 20 & 233 & 9.6 & 23.9 & 8.24 & 3.3 & 3.3 \\
\hline April & 23.5 & 40 & 27 & 190 & 9.5 & 24.2 & 7.71 & 10.9 & 10.7 \\
\hline May & 23.8 & 38.3 & 47 & 156 & 8.9 & 22.9 & 6.52 & 60.6 & 54.7 \\
\hline June & 22.5 & 35.1 & 65 & 156 & 8 & 21 & 5.45 & 99.7 & 83.8 \\
\hline July & 21.7 & 32.1 & 78 & 156 & 6.7 & 19.2 & 4.47 & 134.9 & 105.8 \\
\hline August & 21.2 & 31.4 & 82 & 156 & 6.6 & 19.4 & 4.27 & 163.1 & 120.5 \\
\hline September & 20.7 & 32.8 & 83 & 112 & 7.3 & 20.4 & 4.39 & 98.7 & 83.1 \\
\hline October & 20.2 & 35.2 & 68 & 156 & 8.5 & 21.2 & 5.14 & 61 & 55 \\
\hline November & 18.7 & 36.4 & 37 & 233 & 9.4 & 21.1 & 6.79 & 0.9 & 0.9 \\
\hline December & 17.9 & 34.9 & 30 & 268 & 9.4 & 20.2 & 7.08 & 0 & 0 \\
\hline Average & 20.7 & 35.5 & 48 & 196 & 8.6 & 21.4 & 6.28 & 633.1 & 517.9 \\
\hline \multicolumn{10}{|c|}{ Site 9} \\
\hline Month & Min Temp & Max Temp & Humidity & Wind & Sun & Rad & ETo & Rain & Eff Rain \\
\hline & ${ }^{\circ} \mathrm{C}$ & ${ }^{\circ} \mathrm{C}$ & $\%$ & $\mathrm{~km} /$ day & hours & $\mathrm{MJ} / \mathrm{m}^{2} /$ day & $\mathrm{mm} /$ day & $\mathrm{mm}$ & $\mathrm{mm}$ \\
\hline January & 16.1 & 32.3 & 26 & 268 & 10.2 & 21.9 & 6.99 & 0 & 0 \\
\hline February & 19.1 & 35.1 & 21 & 311 & 10 & 23.1 & 8.44 & 0 & 0 \\
\hline March & 22.6 & 38.1 & 19 & 268 & 9.1 & 23.1 & 8.67 & 0.9 & 0.9 \\
\hline April & 24.5 & 40.1 & 21 & 190 & 9.3 & 23.9 & 7.81 & 6.2 & 6.1 \\
\hline May & 25.7 & 39.3 & 38 & 190 & 9.1 & 23.2 & 7.4 & 21.7 & 20.9 \\
\hline June & 19.5 & 36.3 & 54 & 190 & 8.1 & 21.3 & 6.16 & 88 & 75.6 \\
\hline July & 22.9 & 32.7 & 66 & 190 & 6.5 & 19 & 5.01 & 125.2 & 100.1 \\
\hline August & 22.7 & 32.3 & 71 & 190 & 6.8 & 19.8 & 4.89 & 125.3 & 100.2 \\
\hline September & 22.6 & 33.6 & 66 & 190 & 7.6 & 20.8 & 5.31 & 107 & 88.7 \\
\hline October & 23 & 35.9 & 45 & 190 & 8.6 & 21.3 & 6.23 & 22.9 & 22.1 \\
\hline November & 20.7 & 35.7 & 28 & 233 & 10.3 & 22.2 & 7.17 & 0.1 & 0.1 \\
\hline December & 17.5 & 34.7 & 25 & 233 & 10.1 & 21.1 & 6.87 & 0 & 0 \\
\hline Average & 21.4 & 35.5 & 40 & 220 & 8.8 & 21.7 & 6.75 & 497.3 & 414.7 \\
\hline \multicolumn{10}{|c|}{ Site 10} \\
\hline Month & Min Temp & Max Temp & Humidity & Wind & Sun & Rad & ETo & Rain & Eff Rain \\
\hline & ${ }^{\circ} \mathrm{C}$ & ${ }^{\circ} \mathrm{C}$ & $\%$ & $\mathrm{~km} /$ day & hours & $\mathrm{MJ} / \mathrm{m}^{2} /$ day & $\mathrm{mm} /$ day & $\mathrm{mm}$ & $\mathrm{mm}$ \\
\hline January & 17.2 & 34.7 & 39 & 268 & 8.7 & 19.2 & 6.48 & 0 & 0 \\
\hline February & 18.3 & 36.4 & 31 & 268 & 9.1 & 21.3 & 7.39 & 0 & 0 \\
\hline March & 21.6 & 39.2 & 28 & 268 & 8.7 & 22.3 & 8.28 & 0.5 & 0.5 \\
\hline April & 23.8 & 41 & 25 & 233 & 8.9 & 23.2 & 8.42 & 3.4 & 3.4 \\
\hline
\end{tabular}


Table A1. Cont.

\begin{tabular}{|c|c|c|c|c|c|c|c|c|c|}
\hline May & 25.2 & 40.6 & 36 & 233 & 9 & 23.3 & 8.16 & 21.2 & 20.5 \\
\hline June & 23.4 & 37.5 & 53 & 268 & 8.4 & 22 & 7.22 & 90.9 & 77.7 \\
\hline July & 21.6 & 33.4 & 70 & 268 & 6.7 & 19.5 & 5.42 & 183.4 & 129.6 \\
\hline August & 21.2 & 32.2 & 76 & 268 & 6.9 & 19.9 & 4.95 & 184.4 & 130 \\
\hline September & 21.4 & 34.1 & 70 & 233 & 7.7 & 20.7 & 5.34 & 85.5 & 73.8 \\
\hline October & 22.1 & 36.8 & 55 & 156 & 8.3 & 20.3 & 5.5 & 31.4 & 29.8 \\
\hline November & 21 & 37.1 & 38 & 190 & 8.9 & 19.7 & 6.12 & 3 & 3 \\
\hline December & 18.1 & 35.2 & 40 & 233 & 9.1 & 19.1 & 6.13 & 0 & 0 \\
\hline Average & 21.2 & 36.5 & 47 & 240 & 8.4 & 20.9 & 6.62 & 603.7 & 468.2 \\
\hline \multicolumn{10}{|c|}{ Site 11} \\
\hline \multirow[t]{2}{*}{ Month } & Min Temp & Max Temp & Humidity & Wind & Sun & Rad & ETo & Rain & Eff Rain \\
\hline & ${ }^{\circ} \mathrm{C}$ & ${ }^{\circ} \mathrm{C}$ & $\%$ & $\mathrm{~km} /$ day & hours & $\mathrm{MJ} / \mathrm{m}^{2} /$ day & $\mathrm{mm} / \mathrm{day}$ & $\mathrm{mm}$ & $\mathrm{mm}$ \\
\hline January & 6.8 & 28.5 & 32 & 164 & 9.2 & 19.7 & 4.7 & 0 & 0 \\
\hline February & 7.2 & 29.1 & 30 & 138 & 9.7 & 22 & 4.82 & 0 & 0 \\
\hline March & 11.5 & 33.1 & 28 & 164 & 9.7 & 23.7 & 5.94 & 0 & 0 \\
\hline April & 16.2 & 35.5 & 26 & 164 & 10 & 25 & 6.62 & 1 & 1 \\
\hline May & 18.6 & 36.3 & 26 & 156 & 10.2 & 25 & 6.7 & 5 & 5 \\
\hline June & 20.5 & 36 & 33 & 164 & 9.5 & 23.7 & 6.63 & 15 & 14.6 \\
\hline July & 20 & 33 & 48 & 138 & 7.7 & 21 & 5.48 & 71 & 62.9 \\
\hline August & 19 & 30.1 & 63 & 138 & 7.5 & 21 & 4.83 & 118 & 95.7 \\
\hline September & 18 & 33 & 48 & 138 & 8.5 & 22 & 5.41 & 25 & 24 \\
\hline October & 15.8 & 33.2 & 35 & 138 & 9.3 & 21.8 & 5.48 & 4 & 4 \\
\hline November & 11.1 & 30.3 & 33 & 138 & 9.2 & 20 & 4.78 & 0 & 0 \\
\hline December & 7.6 & 28.7 & 32 & 138 & 9.2 & 19.1 & 4.36 & 0 & 0 \\
\hline Average & 14.4 & 32.2 & 36 & 148 & 9.1 & 22 & 5.48 & 239 & 207.2 \\
\hline \multicolumn{10}{|c|}{ Site 12} \\
\hline Month & Min Temp & Max Temp & Humidity & Wind & Sun & Rad & ETo & Rain & Eff Rain \\
\hline & ${ }^{\circ} \mathrm{C}$ & ${ }^{\circ} \mathrm{C}$ & $\%$ & $\mathrm{~km} /$ day & hours & $\mathrm{MJ} / \mathrm{m}^{2} /$ day & $\mathrm{mm} / \mathrm{day}$ & $\mathrm{mm}$ & $\mathrm{mm}$ \\
\hline January & 9.5 & 23.3 & 41 & 311 & 10.5 & 19.1 & 4.8 & 0.1 & 0.1 \\
\hline February & 10.5 & 25.7 & 31 & 346 & 10.9 & 21.8 & 6.2 & 0 & 0 \\
\hline March & 14.6 & 30.5 & 20 & 346 & 11 & 24.5 & 8.1 & 0 & 0 \\
\hline April & 19.4 & 36.1 & 17 & 346 & 11.4 & 26.7 & 9.89 & 0 & 0 \\
\hline May & 23.3 & 39.6 & 18 & 346 & 11.9 & 27.9 & 10.94 & 0 & 0 \\
\hline June & 25 & 41.1 & 15 & 311 & 11.6 & 27.4 & 10.85 & 0 & 0 \\
\hline July & 24.9 & 40.7 & 21 & 233 & 11.2 & 26.7 & 9.21 & 0 & 0 \\
\hline August & 24.9 & 40.1 & 25 & 268 & 10.6 & 25.4 & 9.34 & 0.5 & 0.5 \\
\hline September & 24.4 & 39.2 & 25 & 423 & 10.6 & 24.2 & 11.13 & 0 & 0 \\
\hline October & 21.5 & 36.1 & 28 & 389 & 10.4 & 21.7 & 9.29 & 0 & 0 \\
\hline November & 15.7 & 29.2 & 39 & 346 & 10.1 & 19 & 6.4 & 0 & 0 \\
\hline December & 11.3 & 24.8 & 41 & 311 & 10 & 17.8 & 4.98 & 0 & 0 \\
\hline Average & 18.8 & 33.9 & 27 & 331 & 10.9 & 23.5 & 8.43 & 0.6 & 0.6 \\
\hline
\end{tabular}

\section{References}

1. Special Report-2020/21 FAO Crop and Food Supply Assessment Mission (CFSAM) to the Republic of the Sudan; Food and Agriculture Organization of the United Nations: Rome, Italy, 2021. [CrossRef]

2. Peel, M.C.; Finlayson, B.L.; McMahon, T.A. Updated world map of the Köppen-Geiger climate classification. Hydrol. Earth Syst. Sci. 2007, 11, 1633-1644. [CrossRef]

3. University of East Anglia Climatic Research Unit. Available online: https://lr1.uea.ac.uk/cru/data (accessed on 13 June 2021).

4. Harris, I.; Jones, P.D.; Osborn, T.J.; Lister, D.H. Updated high-resolution grids of monthly climatic observations-the CRU TS3. 10 Dataset. Int. J. Climatol. 2014, 34, 623-642. [CrossRef]

5. British Geological Survey Climate of Sudan. Available online: http://earthwise.bgs.ac.uk/index.php/Climate_of_Sudan (accessed on 13 June 2021).

6. Ahmed, S.M. Impacts of drought, food security policy and climate change on performance of irrigation schemes in Sub-saharan Africa: The case of Sudan. Agric. Water Manag. 2020, 232, 106064. [CrossRef]

7. Shankar Naik, B. Functional roles of fungal endophytes in host fitness during stress conditions. Symbiosis 2019, 79, 99-115. [CrossRef] 
8. Redman, R.S.; Kim, Y.O.; Woodward, C.J.D.A.; Greer, C.; Espino, L.; Doty, S.L.; Rodriguez, R.J. Increased fitness of rice plants to abiotic stress via habitat adapted symbiosis: A strategy for mitigating impacts of climate change. PLoS ONE 2011, 6, e14823. [CrossRef] [PubMed]

9. Acuña-Rodríguez, I.S.; Newsham, K.K.; Gundel, P.E.; Torres-Díaz, C.; Molina-Montenegro, M.A. Functional roles of microbial symbionts in plant cold tolerance. Ecol. Lett. 2020, 23, 1034-1048. [CrossRef]

10. Decunta, F.A.; Pérez, L.I.; Malinowski, D.P.; Molina-Montenegro, M.A.; Gundel, P.E. A Systematic Review on the Effects of Epichloë Fungal Endophytes on Drought Tolerance in Cool-Season Grasses. Front. Plant Sci. 2021, 12, 380. [CrossRef]

11. Suryanarayanan, T.S.; Shaanker, R.U. Can fungal endophytes fast-track plant adaptations to climate change? Fungal Ecol. 2021, 50, 101039. [CrossRef]

12. Valipour, M. Land use policy and agricultural water management of the previous half of century in Africa. Appl. Water Sci. 2015, 5, 367-395. [CrossRef]

13. Burney, J.A.; Naylor, R.L.; Postel, S.L. The case for distributed irrigation as a development priority in sub-Saharan Africa. Proc. Natl. Acad. Sci. USA 2013, 110, 12513-12517. [CrossRef]

14. Elhag, A.E.; Abdelkarim, A.A. Analysis of Irrigation Water Requirements in Gezira Scheme Using Geographic Information Systems: Case Study Block Number 26 (Dolga). J. Eng. Comput. Sci. 2021, 22, 81-91.

15. Food and Agriculture Organization of the United Nations, Cropwat. Available online: https://www.fao.org/land-water/ databases-and-software/cropwat/en/ (accessed on 20 April 2021).

16. Barnett, T. Why are bureaucrats slow adopters? The case of water management in the Gezira scheme. Sociol. Rural. 1979, 19, 60-70. [CrossRef]

17. Elshaikh, A.E.; Yang, S.; Jiao, X.; Elbashier, M.M. Impacts of Legal and Institutional Changes on Irrigation Management Performance: A Case of the Gezira Irrigation Scheme, Sudan. Water 2018, 10, 1579. [CrossRef]

18. British Geological Survey Hydrology of Sudan. Available online: http:/ / earthwise.bgs.ac.uk/index.php/Africa_Groundwater_ Atlas_Hydrogeology_Maps (accessed on 15 May 2021).

19. MacDonald, A.M.; Bonsor, H.C.; Dochartaigh, B.É.Ó.; Taylor, R.G. Quantitative maps of groundwater resources in Africa. Environ. Res. Lett. 2012, 7, 24009. [CrossRef]

20. MacDonald, A.M.; Davies, J. A Brief Review of Groundwater for Rural Water Supply in Sub-Saharan Africa; BGS Technical Report WC/00/33 2000; BGS: Nottinghamshire, UK, 2000.

21. Saeed, T.M. Sustainable energy potential in Sudan. J. Eng. Comput. Sci. 2020, 20, 1-10.

22. Fadlallah, S.O.; Serradj, D.E.B. Determination of the optimal solar photovoltaic (PV) system for Sudan. Sol. Energy 2020, 208, 800-813. [CrossRef] [PubMed]

23. Schumacher, J.; Luedeling, E.; Gebauer, J.; Saied, A.; El-Siddig, K.; Buerkert, A. Spatial expansion and water requirements of urban agriculture in Khartoum, Sudan. J. Arid Environ. 2009, 73, 399-406. [CrossRef]

24. Jabow, M.; Salih, A.; Abdelhadi, A.; Ahmed, B. Crop water requirements for tomato, common bean and chick pea in Hudeiba, River Nile State, Sudan. Sudan J. Agric. Res. 2013, 22, 11-22.

25. Mappr States of Sudan. Available online: https://www.mappr.co/counties/states-of-sudan/ (accessed on 22 August 2021).

26. Guidelines for Soil Description; Food and Agriculture Organization of the United Nations: Rome, Italy, 2006 ; ISBN 9251055211.

27. Allen, R.G.; Pereira, L.S.; Raes, D.; Smith, M. Crop evapotranspiration-Guidelines for computing crop water requirements-FAO Irrigation and drainage paper 56. Fao Rome 1998, 300, D05109.

28. Penman, H.L. Evaporation: An introductory survey. Neth. J. Agric. Sci. 1956, 4, 9-29. [CrossRef]

29. Ewaid, S.H.; Abed, S.A.; Al-Ansari, N. Crop water requirements and irrigation schedules for some major crops in southern Iraq. Water 2019, 11, 756. [CrossRef]

30. Protogeropoulos, C.; Pearce, S. Laboratory evaluation and system sizing charts for a 'second generation'direct PV-powered, low cost submersible solar pump. Sol. energy 2000, 68, 453-474. [CrossRef]

31. Mahmoud, S.D.M. Sudan Subgrade Soils Characteristics. IOSR J. Eng. 2014, 4, 48-56. [CrossRef]

32. Country Profile-Sudan; Food and Agriculture Organization of the United Nations: Rome, Italy, 2015.

33. Abdallah, N.A. The Story behind Bt Cotton: Where does Sudan stand? GM Crop. Food 2014, 5, 241-243. [CrossRef] [PubMed]

34. Kose, F.; Aksoy, M.H.; Ozgoren, M. Experimental investigation of solar/wind hybrid system for irrigation in Konya, Turkey. Therm. Sci. 2019, 23, 4129-4139. [CrossRef]

35. Elkadeem, M.R.; Wang, S.; Sharshir, S.W.; Atia, E.G. Feasibility analysis and techno-economic design of grid-isolated hybrid renewable energy system for electrification of agriculture and irrigation area: A case study in Dongola, Sudan. Energy Convers. Manag. 2019, 196, 1453-1478. [CrossRef] 